\title{
Review
}

\section{Heart Failure in Patients with Arrhythmogenic Cardiomyopathy}

\author{
Shi Chen ${ }^{1}$, Liang Chen ${ }^{1, *}$, Firat Duru ${ }^{2,3}$ and Shengshou $\mathrm{Hu}^{1}$ \\ 1 Department of Cardiac Surgery, State Key Laboratory of Cardiovascular Disease, Fuwai Hospital, National \\ Center for Cardiovascular Diseases, Chinese Academy of Medical Sciences and Peking Union Medical \\ College, 167A Beilishi Road, Xi Cheng District, Beijing 100037, China; chenshi@fuwai.com (S.C.); \\ huss@fuwaihospital.org (S.H.) \\ 2 Arrhythmia and Electrophysiology, Department of Cardiology, University Heart Center Zurich, \\ Rämistrasse 100, CH-8091 Zurich, Switzerland; firat.duru@usz.ch \\ 3 Center for Integrative Human Physiology, University of Zurich, Rämistrasse 100, \\ CH-8091 Zurich, Switzerland \\ * Correspondence: chenliang@fuwaihospital.org
}

Citation: Chen, S.; Chen, L.; Duru, F.; $\mathrm{Hu}, \mathrm{S}$. Heart Failure in Patients with Arrhythmogenic Cardiomyopathy. J. Clin. Med. 2021, 10, 4782. https:// doi.org/10.3390/jcm10204782

Academic Editors: Sophie I. Mavrogeni and Maciej Banach

Received: 7 September 2021

Accepted: 14 October 2021

Published: 19 October 2021

Publisher's Note: MDPI stays neutral with regard to jurisdictional claims in published maps and institutional affiliations.

Copyright: (c) 2021 by the authors. Licensee MDPI, Basel, Switzerland. This article is an open access article distributed under the terms and conditions of the Creative Commons Attribution (CC BY) license (https:// creativecommons.org/licenses/by/ $4.0 /)$.

\begin{abstract}
Arrhythmogenic cardiomyopathy (ACM) is a rare inherited cardiomyopathy characterized as fibro-fatty replacement, and a common cause for sudden cardiac death in young athletes. Development of heart failure (HF) has been an under-recognized complication of ACM for a long time. The current clinical management guidelines for HF in ACM progression have nowadays been updated. Thus, a comprehensive review for this great achievement in our understanding of HF in $\mathrm{ACM}$ is necessary. In this review, we aim to describe the research progress on epidemiology, clinical characteristics, risk stratification and therapeutics of HF in ACM.
\end{abstract}

Keywords: arrhythmogenic ventricular cardiomyopathy; heart failure; risk stratification; prognosis

\section{Introduction}

Arrhythmogenic cardiomyopathy (ACM) is a familial heart disease with a prevalence of approximately 1:5000 [1-3]. The disease is a major cause of sudden cardiac death (SCD) in adolescents and young adults, especially during athletic activity. With the establishment of clinical risk prediction models and the use of implantable cardioverter-defibrillators (ICD) in high-risk patients, the incidence of malignant arrhythmic events has gradually reduced [4-8]. ACM is known to be a progressive disease, and with advanced right ventricular (RV) involvement and/or left ventricular (LV) involvement, symptoms and signs of heart failure (HF) may occur during later stages of disease. Despite the fact that the focus in ACM was on arrhythmias in earlier studies, various HF phenotypes have received attention more recently.

The prevalence and severity of progressive HF in ACM have been somewhat controversial, as the epidemiological and clinical characteristics of the disease varied greatly among reports from different centers [9-12]. In many retrospective clinical studies, HF was reported to be rare and often related to later stages of disease $[13,14]$. On the other hand, HF was also reported to be an early, and even first, manifestation of disease in other studies. In particular, it has even been recognized as one of the main causes for cardiac death and heart transplantation (HTx) [10,12].

The HF course of ACM is unique from other cardiac diseases, such as dilated cardiomyopathy and hypertrophic cardiomyopathy, which are more common causes for severe HF related adverse outcomes. The sequence and origin of HF symptoms in ACM is quite distinctive. The symptoms of HF often appear after the stage of electrophysiological disorder and originate from the right side pulmonary circulatory system in ACM. The severity of ACM has gender specificity and age differences, which could lead to different risk stratification from other cardiomyopathies. Apart from that, the genotype and exercise 
could also affect the HF progression in ACM, which requires a more specific prevention and treatment strategy in its clinical management.

In this review, in order to provide a more comprehensive understanding of clinical phenotypes and management strategies, we report the prevalence, clinical course, risk stratification, prevention and treatment strategies of HF in ACM patients. Moreover, we propose our view of prospective research directions in this field.

The ACM studies included in this review were found on PubMed, Embase. We combined arrhythmogenic right ventricular cardiomyopathy/dysplasia OR ARVC/D (arrhythmogenic right ventricular cardiomyopathy/dysplasia) with heart failure OR cardiac dysfunction OR cardiac insufficiency as keywords and MeSH terms, and manually searched the reference lists of key reviews and all potentially relevant studies. The search was performed from its inception until 15 September 2021.

\section{Prevalence of HF in ACM}

Progressive disease and occurrence of $\mathrm{HF}$ was described in various ACM registries across different ethnic backgrounds. HF has been reported from all ACM cohorts across the globe (Figure 1). However, the prevalence of HF in this disease was reported differently in different centers because of the lack of consensus on the definition of HF and due to different inclusion methods. The clinical diagnosis of HF was mainly based on a combination of the American College of Cardiology/ American Heart Association HF staging system and physician experience in different registries. The incidence of HF was reported to be in the range of $5 \%$ (defined by volume overload) to $49 \%$ (defined by the clinical symptoms and the severity of ventricular remodeling in echocardiogram or cardiac MRI imagines) among different centers and studies $[10,15]$. In the clinical reports from studies which only include the ACM probands, the incidence of HF was higher compared to some others which also enrolled their at-risk relatives. The incidence of HF in ACM was reported to be around $0.5 \%$ annually in primary care hospitals, which was much lower than that reported by tertiary care centers [16]. The causes of this difference may mainly derive from the unavoidable selection bias of the ACM population, in that patients with advanced HF were more likely treated in tertiary hospitals.

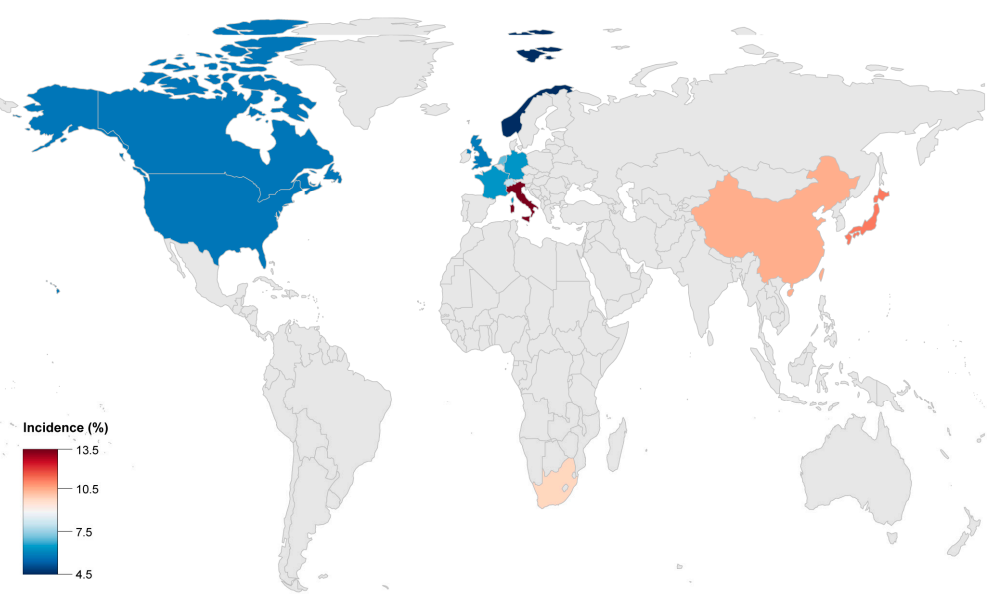

Figure 1. The incidence of heart transplantation/death reported from the ACM registry in different countries worldwide.

The global incidence of adverse outcomes, including HTx and cardiac death caused by HF in ACM, was reported to be 2 to $22 \%$ (Table 1). Advanced HF in ACM was more common in Asia and could cause a poorer prognosis compared with Europe or America. The ACM patients from China or Japan had higher risk for HF related rehospitalization, heart transplantation and death. This could possibly be caused by the different proportion of certain gene mutations, such as plakophilin 2 (PKP2) and Desmoglein 2 (DSG2). 
Table 1. Details of heart failure studies in ACM registries.

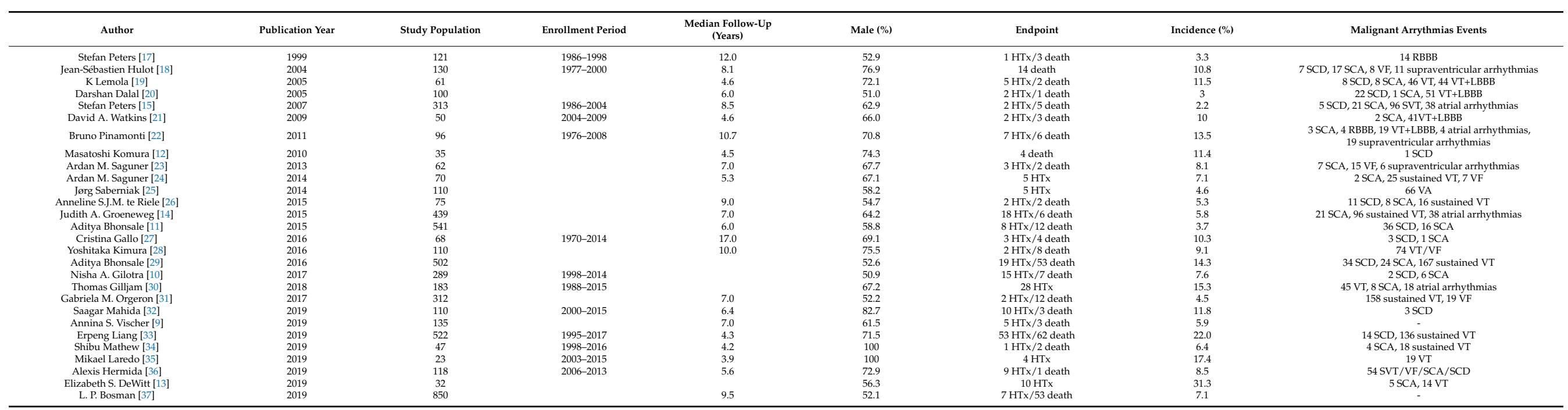

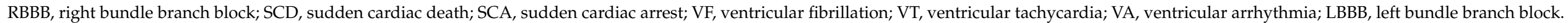




\section{Clinical Characteristics and Classification}

\subsection{Clinical Characteristics}

\subsubsection{Clinical Course and Symptoms}

Electrical instability and progressive HF are the typical phenotypes of ACM. The symptoms such as fatigue, dyspnea, and edema are often caused by advanced HF [15]. Symptoms of HF may occur at any age, ranging from childhood to the elderly [26,29]. However, later-onset HF was more common in ACM. The prognosis was worse in these patients than other ACM patients who only had arrythmias. The average age of HF presentation was 40 to 46 years, which was approximately 10 years later than occurrence of arrhythmic events, in general [10,30]. The mortality of patients who had first manifestation with HF symptoms was higher than patients who only had ventricular tachyarrhythmias. The risk of adverse outcomes increased significantly if patients were rehospitalized for HF [38].

The clinical course of HF in ACM was reported to be heterogeneous. Some ACM patients reached the endpoint of cardiac death or HTx within 2 or 3 years, while these occurred after a few decades in some patients $[15,29,30]$. The description of HF's course in ACM was limited in most studies and the potential relationship between HF and ventricular arrhythmias was incompletely described [39].

In some opinions, HF and ventricular arrythmias were two independent phenotypes, as the incidence of VT was common for both, and it made no difference whether patients had HF or not $[18,40]$. Besides, clinical management of VT, such as ICD implantation and catheter ablation, couldn't reduce the occurrence of HF and improve its prognosis in ACM [10,12,27,31,32,34,35]. In other points of view, however, HF and ventricular arrythmias occurred successively based on the four sequential clinicopathological stages of the classical ACM (Figure 2) [13,41].

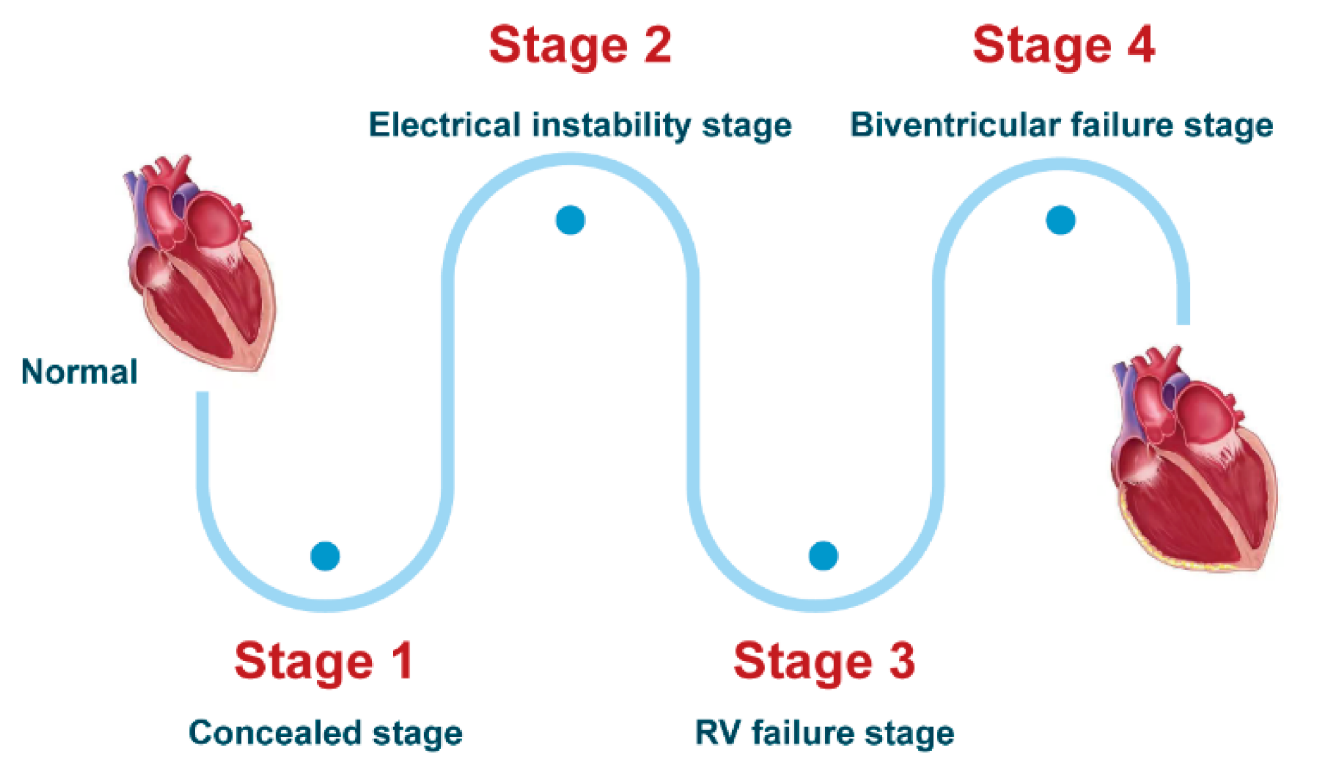

Figure 2. Heart failure progression in classical ACM.

- $\quad$ Stage 1 , the concealed stage, characterized by minor structural changes in RV without obvious abnormality in electrocardiogram (ECG), echocardiogram and histological findings. At this stage, SCD and life-threatening ventricular arrythmias can be the first manifestation in young patients, especially if they are engaged in competitive sports and endurance exercise.

- $\quad$ Stage 2, electrical instability stage, in which RV structural remodeling and dysfunction become an overt phenotype. Recurrent RV arrhythmias such as VT frequently occurred at this stage. 
- $\quad$ Stage 3, RV failure stage, caused by diffuse progressive fibrofatty tissue replacement of RV myocardium in RV. LV function is typically preserved. Symptoms of volume overload and congestive HF appear gradually but are still under control, if proper intervention strategies are used at this stage.

- Stage 4, biventricular HF with global dilation and LV involvement. The proportion of ACM patients to reach this phase was small, which could be influenced by survival bias.

In summary, arrhythmias typically occur in the early phase of ACM, whereas progressive RV failure and LV dysfunction may appear during the later natural course of disease. The clinical course of HF is typically quite different in ACM as compared to other common cardiomyopathies, such as dilated cardiomyopathy, and has unique gene expression patterns. This clinical classification and the stages of $\mathrm{HF}$ were mainly classified based on the natural course of classical ARVC, however, the natural history of other ACM subtypes such as LV dominant ACM still need further study.

\subsubsection{Imaging and ECG Phenotype}

The ARVC patients could have a typical phenotype with both structural abnormalities and electrophysiological disorders, which are often reflected on the results of imaging and ECG tests. The typical CMR and ECG characteristics of ACM HF patients are provided in Figure 3.

A

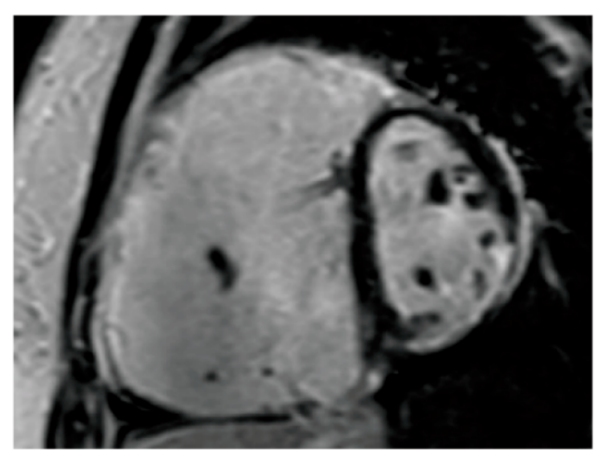

B

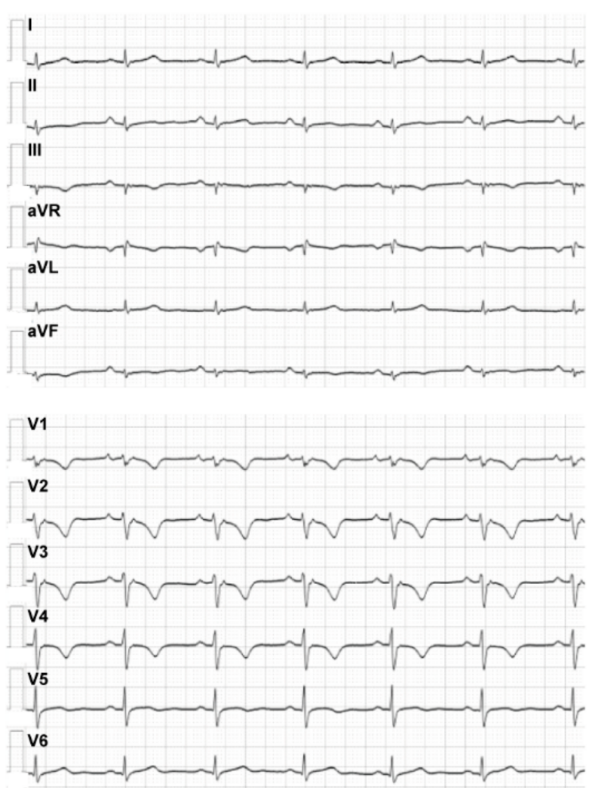

Figure 3. The CMR and ECG characteristics of ACM HF patients. (A) The CMR image of ACM HF patient; (B) the ECG of ACM HF patient. (Adapted with permission from Liang et al. [42]). CMR, cardiac magnetic resonance; ECG, electrocardiogram; ACM, arrhythmogenic cardiomyopathy; $\mathrm{HF}$, heart failure.

The diagnosis of ARVC is determined by the combination of imaging, electrophysiological, pathological examination and family history, based on the 2010 Revised Task Force Criteria (TFC) [43]. The diagnostic criteria of imaging and ECG in 2010 TFC are summarized in Figure 4. 


\begin{tabular}{|c|c|}
\hline \multicolumn{2}{|l|}{ Structure/function assessment } \\
\hline Major & Minor \\
\hline $\begin{array}{l}\text { 2D echocardiography } \\
\text { Regional RV akinesia, dyskinesia or aneurysm and } 1 \text { of the following at end diastole:. } \\
\text { - PLAX RVOT } \geq 32 \mathrm{~mm} \text { or PLAX/BSA } \geq 19 \mathrm{~mm} / \mathrm{m}^{2} \text {. } \\
\text { - PSAX RVOT } \geq 36 \mathrm{~mm} \text { or PSAX/BSA } \geq 21 \mathrm{~mm} / \mathrm{m}^{2} \text {. } \\
\text { - Fractional area change } \leq 33 \% \text {. }\end{array}$ & $\begin{array}{l}\text { Regional RV akinesia, dyskinesia or aneurysm and } 1 \text { of the following at end diastole: } \\
\text { - PLAX RVOT } \geq 29 \text { to }<32 \mathrm{~mm} \text { or PLAX/BSA } \geq 16 \text { to }<19 \mathrm{~mm} / \mathrm{m}^{2} \\
\text { - PSAX RVOT } \geq 32 \text { to }<36 \mathrm{~mm} \text { or PSAX/BSA } \geq 18 \text { to }<21 \mathrm{~mm} / \mathrm{m}^{2} \\
\text { - Fractional area change }>33 \% \text { to } \leq 40 \% \text {. }\end{array}$ \\
\hline $\begin{array}{l}\text { CMR } \\
\text { Regional RV akinesia or dyskinesia or dyssynchronous contraction and } 1 \text { of the following: } \\
- \text { RV EDV/BSA } \geq 110 \mathrm{~mL} / \mathrm{m}^{2} \text { (male) or } \geq 100 \mathrm{~mL} / \mathrm{m}^{2} \text { (female). } \\
- \text { RVEF } \leq 40 \% \text {. }\end{array}$ & $\begin{array}{l}\text { Regional RV akinesia or dyskinesia or dyssynchronous contraction and } 1 \text { of the following (end diastole) } \\
\text { - RV EDV/BSA } \geq 100 \text { to }<110 \mathrm{~mL} / \mathrm{m}^{2} \text { (male) or } \geq 90 \text { to }<100 \mathrm{~mL} / \mathrm{m}^{2} \text { (female). } \\
\text { - RVEF }>40 \text { to } \leq 45 \% \text {. }\end{array}$ \\
\hline
\end{tabular}

\begin{tabular}{|c|c|}
\hline \multicolumn{2}{|l|}{ Repolarisation abnormalities } \\
\hline Major & Minor \\
\hline $\begin{array}{l}\text { Inverted T-waves in leads V1, V2 and V3 or beyond, in individuals > } 14 \text { years of age } \\
\text { (in absence of complete RBBB QRS } \geq 120 \mathrm{~ms} \text { ). }\end{array}$ & $\begin{array}{l}\text { Inverted T-waves in leads } \mathrm{V} 1 \text { and } \mathrm{V} 2 \text {, in individuals }>14 \text { years of age (in absence of complete RBBB) or in V4, V5 or V6. } \\
\text { Inverted T-waves in leads V1, V2, V3 and V4 in individuals }>14 \text { years of age in the presence of complete RBBB. }\end{array}$ \\
\hline \multicolumn{2}{|l|}{ Depolarisation abnormalities } \\
\hline Major & Minor \\
\hline $\begin{array}{l}\text { Epsilon wave (reproducible low-amplitude signals between end of } \\
\text { QRS complete to onset of the T-wave) in V1-3. }\end{array}$ & $\begin{array}{l}\text { Late potentials by SAECG in } \geq 1 \text { of } 3 \text { parameters in absence of a QRS of } \geq 110 \mathrm{~ms} \text { on standard ECG: } \\
\text { - Filtered QRS duration } \geq 114 \mathrm{~ms} \text {. } \\
\text { - Duration of terminal QRS }<40 \mu \mathrm{V} \geq 38 \mathrm{~ms} \text {. } \\
\text { - Root-mean-square voltage of terminal } 40 \mathrm{~ms} \leq 20 \mu \mathrm{V} \text {. } \\
\text { Terminal activation duration of QRS } 255 \mathrm{~ms} \text {, measured from the nadir of the S-wave to the end of } \\
\text { the QRS, including } \mathrm{R}^{\prime} \text {, in } \mathrm{V} 1, \mathrm{~V} 2 \text { or } \mathrm{V} 3 \text {, in absence of complete RBBB. }\end{array}$ \\
\hline \multicolumn{2}{|l|}{ Arrhythmias } \\
\hline Major & Minor \\
\hline Non-sustained or sustained VT of LBBB morphology with superior axis. & $\begin{array}{l}\text { Non-sustained or sustained VT of RVOT configuration, LBBB morphology with inferior axis } \\
\text { or with unknown axis. } \\
>500 \text { PVCs per } 24 \text { hours on Holter monitoring. }\end{array}$ \\
\hline
\end{tabular}

Figure 4. The diagnostic criteria of imaging and ECG in the 2010 Revised Task Force Criteria. 2D, two dimensional; RV, right ventricular; PLAX, parasternal long-axis; RVOT, RV outflow tract; PSAX, parasternal short-axis; BSA, body surface area; CMR, cardiac MRI; EDV, end-diastolic volume; RVEF, right ventricular ejection fraction; RBBB, right bundle branch block; SAECG, signal-averaged ECG; VT, ventricular tachycardia; LBBB, left bundle branch block; PVC, premature ventricular complex.

Cardiac imaging modalities, including echocardiogram and cardiac magnetic resonance (CMR), are reliable methods to make a diagnosis of $\mathrm{ACM}$ and reflect the progression of HF [44]. The echocardiogram examination cannot evaluate the fibrofatty replacement of the myocardium wall and has limited power to precisely measure right ventricular cardiac function [45]. Thus, further CMR examination is the basic modality to make a definite diagnosis of ACM. Apart from the critical role in ACM diagnosis, the abnormalities in echocardiogram and CMR can also indicate the prognosis of HF in ACM patients. The echocardiography presentations in ACM patients with reduced LVEF and tricuspid regurgitation are risk factors for HTx and cardiac death [18,22]. As for CMR parameters, in one report from a prospective study [46] which compared the characteristics of normal controls and ACM patients, significant right ventricular ejection fraction (RVEF) reduction, LV enddiastolic diameter/LV end-systolic dimension (LVEDD/LVEDS) increase, LV global and regional peak strain impairment and higher prevalence of late gadolinium enhancement (LGE) were observed in ACM patients with reduced LVEF. A greater amount of LGE in $\mathrm{LV}$ was mainly localized in the subepicardial wall layers, which also negatively correlated with LVEF [47]. The specific prognostics role of these abnormalities in CMR images in predicting adverse outcomes of HF is still not clarified. However, they could be tested as imaging risk factors for end-stage $\mathrm{HF}$ in the future.

ECG abnormalities, including depolarization and repolarization abnormalities and arrhythmias, can be specific characteristics of ACM [48], which are also among the major diagnostic criteria [43]. Distinct from HF in dilated cardiomyopathy, ACM patients with HF have a higher proportion of low QRS voltages in limb leads, T-wave inversions in the inferolateral leads and major ventricular arrhythmias. Low 12-lead QRS voltage is an independent indicator for heart transplantation in ACM [49]. The inferior leads TWI, a precordial QRS amplitude ratio of $\leq 0.48$ and QRS fragmentation are correlated 
with adverse outcomes, including malignant arrythmias and heart failure events [50]. Additionally, first-degree atrioventricular block and epsilon waves are among the predictors for HF hospitalization [38].

\subsubsection{Plasma Biomarkers}

Plasma biomarkers, which can reflect the severity of HF and, to some degree, predict prognosis, are often used in the clinical practice. According to the findings of ACM cohort studies, biomarkers such as various plasma proteins, noncoding RNA and autoantibodies may be potentially correlated with adverse cardiovascular events, including malignant arrythmias and end-stage heart failure outcomes (Figure 5). In this review, we mainly discuss the application of the plasma biomarker in HF prediction. BNP and NT-proBNP, which are recommended as gold-standard biomarkers for HF by guidelines, can also be applied in HF management. The increase in NT-proBNP is correlated with RV dilation and cardiac dysfunction in ACM [51,52]. Another biomarker as cardiac troponin I (cTnI), which could indicate for cardiomyocyte death and cardiac muscle injury and also correlate with premature ventricular contractions in ACM patients. These classical cardiac biomarkers can reflect the severity of HF in some degree. However, the specificity of NT-proBNP, cTnI and other widely used cardiac biomarkers is low, and their application in ACM patients is still controversial.

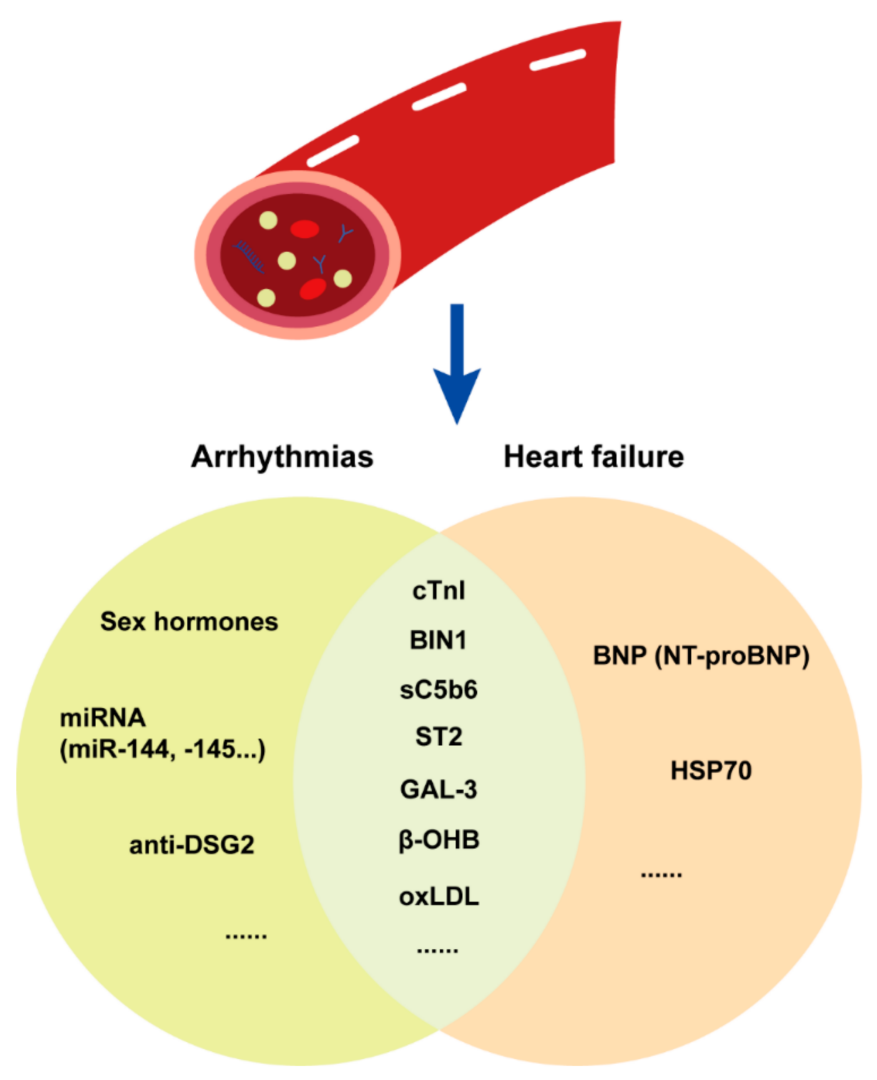

Figure 5. Plasma biomarker application in ACM.

In a proteome study, heat shock protein 70 (HSP70) was significantly elevated in both ACM and other cardiomyopathies [53]. Furthermore, bridging integrator 1 (BIN1) [54,55], ST2 [56] and galectin-3 (GAL-3) [57] can reflect the severity of HF in ACM. The circulation level of complements is also correlated with mortality and cardiac dysfunction in ACM [58]. The sC5b6 level could display the severity of HF, which is significantly higher in ACM patients with biventricular dysfunction compared with isolated RV dysfunction. As is well-known, the abnormality of lipid metabolism is one of the key pathogenesis for ACM progression. The oxidized low-density lipoprotein (ox-LDL) could not only reflect the 
severity of ACM fat infiltration, but also predict the HF and malignant arrhythmia's event risk. Another specific plasma biomarker for ACM clinical course discrimination and cardiac function prediction is $\beta$-hydroxybutyrate ( $\beta-\mathrm{OHB})$. In the report from Fuwai Hospital, the level of $\beta$-OHB is relatively low in healthy volunteers and unsuspected relatives of ACM patients. However, it is gradually increased in ACM patients following the clinical heart failure stage from normal cardiac function to isolated RV dysfunction and biventricular cardiac dysfunction. It could be recognized as a useful predictor for disease progression and adverse heart failure outcomes.

These findings were all from small-sized cohorts with limited numbers of ACM patients with $\mathrm{HF}$, and were not validated by others. Such biomarkers are also not specific for ACM, as end-stage of HF is the common pathway in various cardiomyopathies. The serum levels of these biomarkers are not changed significantly at an early stage and are only evaluated since the onset of advanced HF, which limits their application in early diagnosis and guidance on early intervention. Thus, further proteomics and metabolomics studies on HF biomarkers in ACM are still needed.

\subsubsection{Histopathological Characteristics and Endomyocardial Biopsy}

The hearts from orthotopic HTx and/or autopsies in ACM patients had distinctive histopathological features as compared to other cardiomyopathies. The typical gross morphology and histopathological characteristics of ARVC HF patients are provided in Figure 6.

A

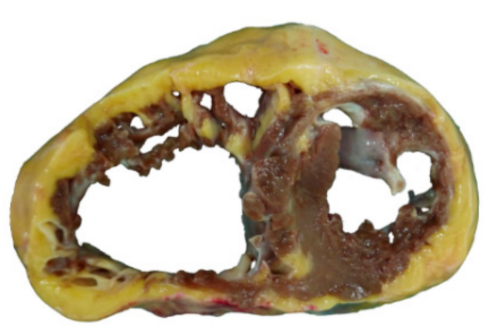

B

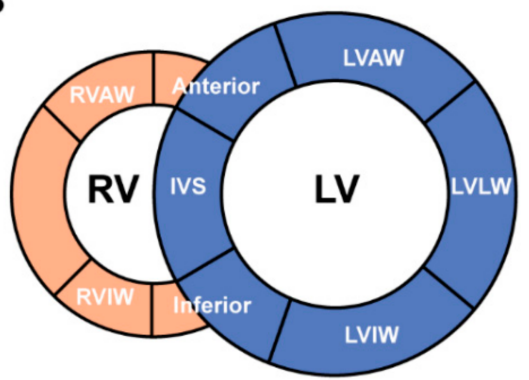

C
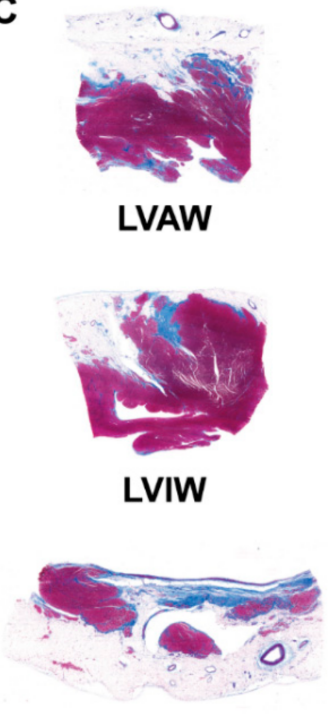

RVAW
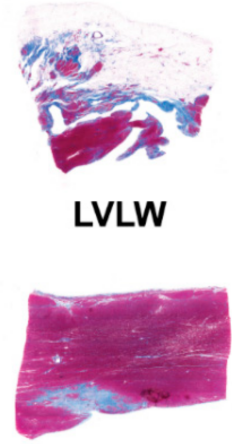

IVS

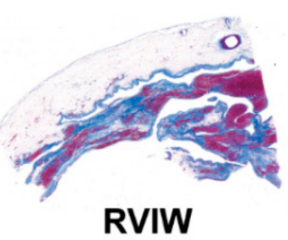

Figure 6. The gross morphology and histopathological characteristics of ARVC HF patients. (A) The explanted heart from ARVC patient; (B) the diagram of sampling position; (C) Masson staining of six representative sections. (Adapted with permission from Liang et al. [42]). LVAW, anterior wall of left ventricular (LV); LVLW, lateral wall of LV; LVIW, inferior wall of LV; IVS, interventricular septum; RVAW, anterior wall of right ventricle (RV); RVIW, inferior wall of RV.

The fibrofatty replacement and cardiomyocyte death in the ventricular myocardium are classical pathological changes in ACM. These histopathological changes commonly start from the RV epicardium, gradually progress into subendocardial layers and demonstrate transmural extension [59]. The endomyocardial biopsy (EMB) is a histopathological evaluation methods to make a definite diagnosis of ARVC, recommended by 2010 TFC and excluding sarcoidosis, myocarditis or other phenocopies that could also lead to uncontrollable HF [3]. However, considering that the sensitivity of EMB was low and the myocardium free wall of RV was thin, its application in ACM patients with HF is still 
controversial. From the recent study, the EMB is safe and helpful for further enhancing the diagnostic efficiency to the arrhythmogenic left ventricular cardiomyopathy, which posed a higher risk to HF stage progression [60]. More evidence will be needed to confirm the clinical value of EMB in the suspension ACM patients.

\subsection{Clinical Classification}

The clinical course and phenotype of ACM is dynamic and distinctive in an individual patient. ACM phenotype was typically divided into four distinct clinical stages [61]. With deeper understanding of the impact of genotype on clinical manifestations, a novel classification (Fuwai Classification) has been recently proposed by our group (Table 2) [42]. In this classification, ACM patients who carried desmosomal mutations, including DSG2, desmocollin 2 (DSC2) and PKP2 in cluster 1, tended to have early onset of HF and reached the endpoint of cardiac death or HTx in a shorter period compared with other subtypes.

Table 2. Fuwai classification of ACM.

\begin{tabular}{|c|c|c|c|c|}
\hline & $\begin{array}{c}\text { Cluster } 1 \\
\text { (Classical ACM) }\end{array}$ & Cluster 2 & Cluster 3 & Cluster 4 \\
\hline Clinical features & $\begin{array}{c}\text { Early-onset disease, } \\
\text { ventricular arrhythmias } \\
\text { common, usually } \\
\text { progressive RV (and later } \\
\text { LV) disease, large RVEDD } \\
\text { on echo, precordial } \\
\text { fractionation and low } \\
\text { voltage, MACE common } \\
\text { during follow-up }\end{array}$ & $\begin{array}{l}\text { Ventricular arrhythmias } \\
\text { common, usually } \\
\text { progressive disease, } \\
\text { moderate-severe LV } \\
\text { dysfunction, precordial } \\
\text { fractionation and } \\
\text { low voltage }\end{array}$ & $\begin{array}{l}\text { Ventricular arrhythmias } \\
\text { common, usually } \\
\text { progressive disease, severe } \\
\text { LV dysfunction, large } \\
\text { LVEDD on echo, } \\
\text { progression to end-stage } \\
\text { heart failure common }\end{array}$ & $\begin{array}{l}\text { Ventricular arrhythmias } \\
\text { common, usually } \\
\text { progressive disease, severe } \\
\text { LV dysfunction, large } \\
\text { LVEDD and LA diameter } \\
\text { on echo, progression to } \\
\text { end-stage heart } \\
\text { failure common }\end{array}$ \\
\hline Histopathology & $\begin{array}{c}\text { Fibrofatty infiltration RV } \\
\text { subepicardial (early), } \\
\text { transmural (late), LV } \\
\text { posterior wall }\end{array}$ & $\begin{array}{l}\text { Fibrofatty infiltration of } \\
\text { RV anterior wall, LV } \\
\text { interstitial fibrosis in full } \\
\text { thickness with only } \\
\text { little fat }\end{array}$ & $\begin{array}{l}\text { Biventricular involvement } \\
\text { with prominent fibrofatty } \\
\text { infiltration, LV } \\
\text { involvement mostly of } \\
\text { inferior wall }\end{array}$ & $\begin{array}{l}\text { LV dominant involvement, } \\
\text { mostly of inferior wall, } \\
\text { with prominent } \\
\text { fibrofatty infiltration }\end{array}$ \\
\hline Genetic variants & $\begin{array}{l}\text { Mostly desmosomal } \\
(P K P 2, D S G 2, D S C 2)\end{array}$ & $\begin{array}{c}\text { Mostly non-desmosomal } \\
\text { (LMNA, PLN, TMEM43, } \\
\text { DES, CTNNA3) }\end{array}$ & $\begin{array}{l}\text { Mostly desmosomal (DSP) } \\
\text { or non-desmosomal } \\
(P L N, C T N N A 3)\end{array}$ & No genetic variants \\
\hline
\end{tabular}

Adapted with permission from Firat et al. [62].

\section{Risk Factors and Stratification}

The risk factors for HF in ACM include demographics factors, electrophysiological abnormalities, genotype and physical activity. The certain genes mutations of ACM patients such as DSG2, desmoplakin (DSP), and phospholamban (PLN) have been proven to be one of the fundamental causes for processive HF, while the factors such as physical activity and arrhythmias often induce or aggravate the HF's progression. However, the role of other malignant arrythmia risk factors in ACM HF such as gender, age or family history might still be controversial (Figure 7). 


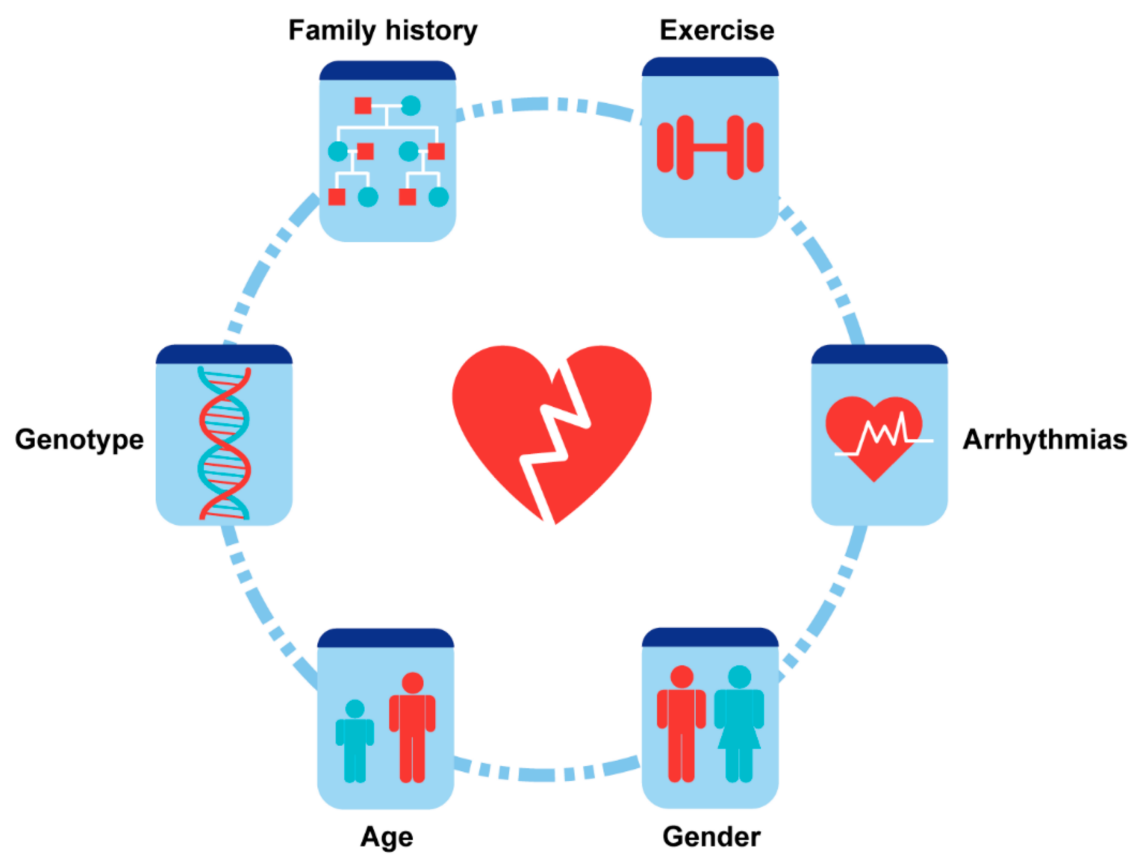

Figure 7. Risk factors of heart failure in ACM.

\subsection{Demographics}

\subsubsection{Gender}

It is well known that gender and sex hormones are important risk factors in ACM. The prevalence of ACM is significantly higher and malignant arrhythmias are often more severe in male patients. However, the HF risk in different genders is still controversial in ACM. [63] According to most reports, there was no obvious gender differences in HF's incidence or severity [28,63-65]. The manifestations of the ECG and echocardiogram were also similar in patients with HF regardless of gender. The combined Johns Hopkins/Netherlands cohort study suggested that the risk of LV involvement and adverse outcomes caused by HF had no difference among the two genders. However, in one study, the risk for cardiac death and HTx caused by HF were reported to be higher in male patients, which was explained by the more competitive exercise patterns in these patients [11]. In contrast, another study found that female sex was an independent risk factor for HF [38]. A potential explanation for this observation was that poor endurance of volume overload and smaller thoracic size often occurred in female patients $[64,65]$. The different role genders play in HF progression among these studies may derive from the balance between the negative effect of sex hormones such as testosterone on cardiomyocytes apoptosis and lower tolerance to HF due to the physiological characteristics of female sex. The limited patient size can also lead to potential selective bias and an impact on the general results in the real world.

\subsubsection{Age}

The average age of onset for ACM is 30-40. It is widely accepted that early-onset of HF often indicates more rapid occurrence of adverse outcomes. On the other hand, in a small cohort with young ACM patients under 18 years and with long-term follow-up, the incidence of adverse HF outcomes was similar in children and adults [26]. In the report from the Nordic ACM Registry, an age of disease onset under 35 years was shown to be an independent risk factor for HTx [30]. In contrast, older patients with late presentation of ACM, who were thought to be more vulnerable, had less risk of cardiac death and HTx than younger patients [29]. 


\subsubsection{Family History and Ethnic Background}

There is widespread consensus that family history is an important risk factor for ventricular arrhythmic events in ACM patients. ACM probands who had symptomatic relatives have a higher possibility for carrying desmosomal mutation and a higher risk of SCD [66]. With respect to the risk of HF, however, most reports showed that familial or isolated ACM probands had the same risk of developing HF [14,19,30]. Meanwhile, no evidence showed that ethnic background could affect the HF risk in ACM patients [10].

\subsection{Arrhythmias and Electrophysiological Abnormalities}

Arrhythmias may occur at any stage of ACM, and over $90 \%$ of patients had an initial manifestation or the history of VT, atrial arrhythmia or aborted SCD $[13,67,68]$. Many studies demonstrated the critical role of arrhythmias in the progression of HF. Theoretically, patients with recurrent VT and atrial arrhythmias tended to have worse hemodynamics features and pump dysfunction [23,32,39]. However, there was no evidence suggesting that VT is a risk factor for HF progression. In addition, the right bundle branch block (RBBB) was reported to have a significant correlation with severe biventricular HF [17]. The development of complete RBBB may lead to poor prognosis [69].

Several studies focused on the characteristics of atrial arrhythmias in ACM and found that these arrhythmias may be common, with a prevalence of about $10-20 \%$ in the general ACM population $[19,30,39]$. The incidence of atrial fibrillation in patients with adverse HF outcomes was 6-19\% [30]. Atrial arrhythmias were associated with increasing mortality and morbidity and appeared to be risk factors for HTx and deaths due to end-stage HF. In addition, the incidence of first-degree atrioventricular block may be significantly higher in patients with rehospitalization for $\mathrm{HF}$, and it was shown to be an independent risk factor for HF hospitalization in ACM [38].

ECG abnormalities may also provide useful information to predict prognosis due to HF in ACM. Prolonged PR intervals, prolonged QRS in lead V1, T wave inversion in leads V4-V5-V6, epsilon waves, presence of bundle branch block and low QRS voltages were reported to be potential risk predictors for adverse outcomes in ACM [19,27]. However, the majority of these studies set their end-point as both lethal arrhythmic events and HTx/death due to HF. A study focusing only on HF outcomes suggested that the precordial QRS amplitudes may be an indicator of RV remodeling and have the potential to predict the progression of HF [68]. Another study of HF in ACM found that the presence of negative T waves in precordial leads V4-V6 was more common in patients with HF symptoms [10]. In addition, the incidence of epsilon waves was significantly higher in patients with HF hospitalization [38].

\subsection{Genotype}

It is well-recognized that ACM is an inherited cardiomyopathy mainly caused by desmosomal mutations. The genotype may also impact the likelihood of developing significant HF during the disease course. Patients carrying DSG2 gene mutations more often demonstrate HF progression compared with PKP2 carriers [9]. Previous studies suggested that patients carrying DSG2 gene mutations tended to have lower LVEF [70]. ACM patients carrying homozygous $\mathrm{p}$. Phe531Cys variant in DSG2 commonly develop severe LV dysfunction and biventricular failure at a young age [71]. DSP and PLN mutations are also correlated with LV involvement [10,11,13,36,72-81]. The risk of irreversible HF in desmosomal rare variant and sarcomeric protein titin (TTN) mutation carriers are slightly higher or similar to other patients [82-84]. Apart from single gene mutations, multi-gene mutation carriers may have an even higher risk of HTx or death due to HF [10,36]. The majority of multi-gene mutation carriers have at least one HF related symptoms [10].

Previous genetic studies of inherited cardiomyopathies demonstrated that the different pattern of gene mutation may lead to distinct prognosis $[11,36,85]$. It is known that PKP2 carriers are more likely develop ventricular arrhythmias, while a study of whole genome sequencing and transcriptome sequencing in heart transplanted ACM patients 
found that recessive variants in PKP2 may lead to early-onset advanced HF [85]. Furthermore, the prognosis of homozygous mutation carriers is much worse than those carrying missense mutations. In some other conditions, however, the risk of severe HF in missense mutations and premature truncating and splice site mutations carriers demonstrates no significant difference [11].

Except for cohort studies, gene-editing animal models mimicking ACM progression also revealed that the genotype was strongly correlated with HF. Myocardium fibrosis and aseptic inflammation were observed at all stages in DSG2 mutation mice [86]. These abnormalities may lead to cardiomyocytes' death, ventricular dilation and HF progression.

\subsection{Physical Activity and Exercise}

There is a general consensus that exercise is an important modulator which could promote ACM's progression and has a significant effect on the prognosis of ACM patients. Endurance exercise and competitive sports may increase the susceptibility to lethal arrhythmic events [87-90]. In fact, intense physical exercise may also aggravate and accelerate myocardial dysfunction and the progression of HF in the ACM population. In a clinical study in ACM athletes, the occurrence of biventricular dysfunction was more common in athletes than in non-athletes and mutation-positive family members in ACM. All HTx occurrences were in the athlete group, while none underwent HTx in the nonathletic group [25]. Competitive exercise is associated with biventricular cardiac dysfunction and elevation of hs-cTnT (high-sensitivity cardiac troponin T) and NT-proBNP [91]. Healthy athletes had physiological changes in myocardial compensatory hypertrophy, mild dilatation of LV and (or) RV and lower normal range of LVEF and (or) RVEF, but these parameters were significantly worse in ACM athletes [25]. The progression of fibro-fatty replacement in RV can also be accelerated because of heavy exercise [92,93]. They all suggested that the amount and intensity of exercise activity had a strong association with the degree of LV and RV function impairment. Thus, ACM patients are recommended to avoid strenuous exercise. However, lifestyle without any activity may also impair the metabolic capacity, muscle strength and mental health of patients. In addition, recreational sport participation with a small amount of activity seems to be harmless with respect to time free from VT and HF in ACM patients [94].

\section{Prevention and Management}

HF is a main cause of HTx and cardiac death in ACM. Timely and effective prevention and management are of great significance to delay or reverse the course of HF progression and improve the survival condition of the ACM patients. Management strategy should be in parallel with the ACM clinicopathological stages based on the 2019 HRS expert consensus statement of ACM [95] and 2021 ESC HF guidelines [96] (Figure 8). Upon the diagnosis of $\mathrm{ACM}$, genetic testing and family screening are necessary. In addition, lifestyle modifications such as exercise restriction and a low-sodium diet are also needed. When electrical instability symptoms have been presented, consistent hemodynamic followup, anti-arrhythmic drug treatment and proper ICD implantation should be considered. These approaches could not only release the burden of arrhythmias, but also delay HF progression. With the aggravation of HF during the $\mathrm{ACM}^{\prime}$ s progression, therapy regimens could add anti-HF and/or antithrombotic drugs. Surgical treatments such as implantation of ventricular assist devices, cardiac resynchronization therapy (CRT) and HTx are the final solutions to end-stage HF in ACM. 


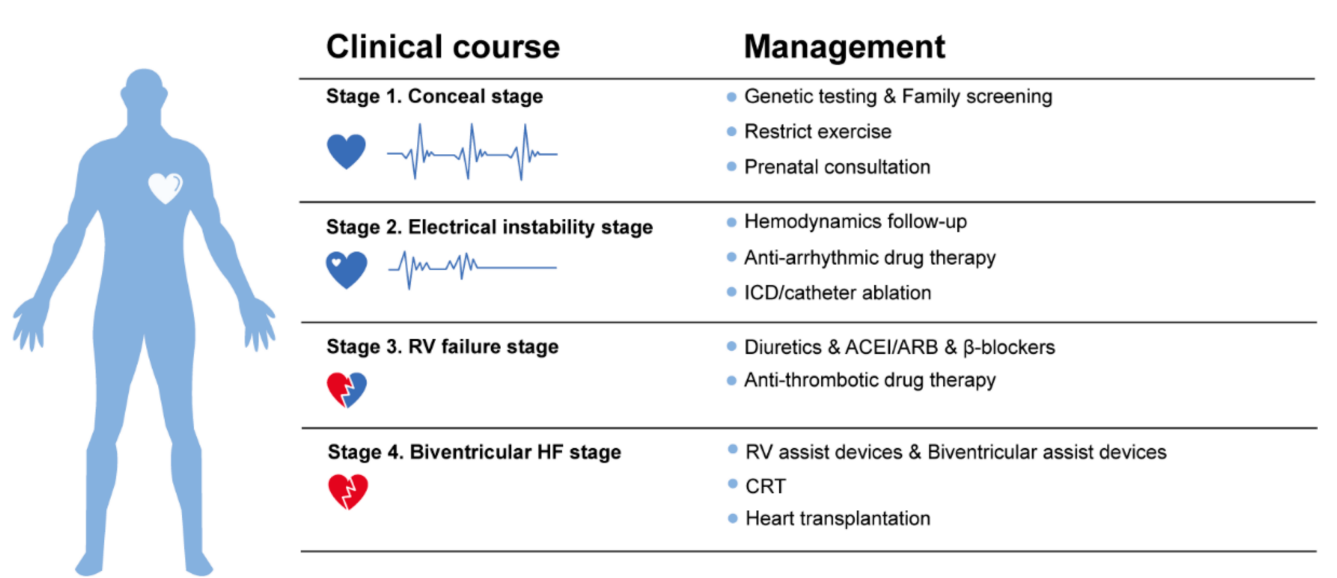

Figure 8. Prevention and management of heart failure in ACM. ICD, implantable cardioverterdefibrillators; ACEI, angiotensin converting enzyme inhibitors; ARB, angiotensin II receptor blockers; $\mathrm{RV}$, right ventricular; CRT, cardiac resynchronization therapy.

\subsection{Prevention}

There is no specific drug aimed at reversing the clinical course of HF in ACM [9], so screening and prevention at an early stage is particularly important. As mentioned above, genotype has a strong correlation with the phenotype and prognosis of ACM. Thus, genetic testing and family screening after definite diagnosis is necessary. Hemodynamic disorders can also influence the progression of HF, and therefore, careful hemodynamic follow-up shall be advised [36].

According to the limited case reports from different centers, pregnancy in ACM is safe and can be well-tolerated. Besides, repeated pregnancies do not seem to correlate with worse outcomes [36]. However, larger cohort studies in pregnant patients are still lacking. Considering that pregnancy will increase the volume overload and circulatory demand, additional risk may be added to pregnant women with ACM, especially to those patients with RV dysfunction and LV involvement. Prenatal consultation can be advised to lower the risk of $\mathrm{HF}$ in ACM patients [97].

\subsection{Drug Therapy}

At the early stage of HF, application of loop diuretics and aldosterone antagonists in patients with volume overload can reduce preload effectively [10]. The clinical benefit of angiotensin-converting enzyme inhibitors (ACEI) and angiotensin receptor blockers (ARB) in HF therapy has been widely accepted. In asymptomatic patients with LVEF $<45 \%$, a combined application of ACEI/ARB can be recommended. In symptomatic patients, beta-blockers, spironolactone, ivabradine and loop diuretics may be considered. In ACM patients with LV involvement and $\mathrm{HF}$, standardized therapy can be recommended based on the 2021 ESC guidelines [96]. Some patients with biventricular HF can improve, with complete or partial recovery of LV functions [16]. RV dilation and RV failure may be difficult to control with therapy. To improve RV failure in ACM, phosphodiesterase type 5 inhibitors may be used, which may improve heart contractility in acute RV failure patients [98]. Moreover, 17-beta-estradiol may also protect cardiomyocytes from cell apoptosis and fibrofatty replacement to some degree at an early stage [99].

Thromboembolic complications may also occur in ACM due to ventricular aneurysms or ventricular dilatation, etc., and long-term oral anticoagulation may be needed in some patients who develop RV or LV thrombi $[100,101]$.

\subsection{Defibrillator Implantation}

The SCD is one of the most dangerous events, and it could occur in nearly $20 \%$ of ACM patients. An appropriate ICD implantation could lower the risk of SCD and other life-threatening arrythmias significantly. Additionally, it should be noted that the stable 
hemodynamic may be fundamental to reducing the risk of thrombosis and delaying HF progression. Although there is still no solid clinical evidence that ICD implantation can be beneficial for decreasing the risk of HF related death or HTx, it's still one of the most important therapies in ACM patients. The clinical decision to pursue ICD implantation should be made by both physicians and patients. The ICD implantation criteria could be based on the risk prediction model for ventricular arrhythmias [5] and the 2019 HRS expert consensus statement [95].

\subsection{Surgical Therapy}

The effect of surgical therapy in HF treatment of ACM patients is still controversial. There is no solid evidence that surgical operations including ventriculoplasty [102], RV disarticulation [103], beating heart cryoablation [104] and left cardiac sympathetic denervation [105] can prolong the survival time of ACM patients who were at end-stage HF. LV assist devices (LVAD) and biventricular assist devices (BVAD) may also be indicated to bridge patients to HTx [9]. LVAD and BVAD support can supply steady circulation and successfully prolong the survival of ACM patients who await HTx. However, no apparent RV functional recovery or symptom improvement were reported during the bridge period [106-109]. Besides, after the implantation of LVAD, the contractile properties of the RV will decrease, and the haemodynamics disorder in RV could aggravate right side HF [110]. Thus, LVAD may not be recommended to patients with isolated RV failure and preserved LVEF. In rare cases, the CRT may be applied [97,111]. More evidence is needed to support the positive impact of CRT for HF management in patients with ACM.

The only standard therapy for advanced HF in ACM is HTx, and the 2016 International Society for Heart and Lung Transplantation heart transplant listing recommendations can be applicable for judging the indication of operation [112]. The survival condition is favorable after HTx, as the five-year survival rate was reported to be $80-90 \%[30,113,114]$. Since the course and characteristics of HF in children and adults are basically similar, the prevention and treatment principles of adults are also applicable for children [26].

Author Contributions: Conceptualization, S.C. and L.C.; methodology, S.C.; writing-original draft preparation, S.C.; writing-review and editing, F.D. and S.H.; visualization, S.C.; supervision, L.C.; project administration, L.C.; funding acquisition, L.C. All authors have read and agreed to the published version of the manuscript.

Funding: This review was supported by Fundamental Research Funds for the Central Universities [3332019047].

Institutional Review Board Statement: Not applicable.

Informed Consent Statement: Not applicable.

Data Availability Statement: Not applicable.

Conflicts of Interest: The authors declare no conflict of interest.

\section{References}

1. Basso, C.; Corrado, D.; Marcus, F.I.; Nava, A.; Thiene, G. Arrhythmogenic right ventricular cardiomyopathy. Lancet 2009, 373, 1289-1300. [CrossRef]

2. Corrado, D.; Link, M.S.; Calkins, H. Arrhythmogenic Right Ventricular Cardiomyopathy. N. Engl. J. Med. $2017,376,61-72$. [CrossRef]

3. Hoorntje, E.T.; Te Rijdt, W.P.T.; James, C.A.; Pilichou, K.; Basso, C.; Judge, D.P.; Bezzina, C.R.; Van Tintelen, J.P. Arrhythmogenic cardiomyopathy: Pathology, genetics, and concepts in pathogenesis. Cardiovasc. Res. 2017, 113, 1521-1531. [CrossRef]

4. Bosman, L.P.; Sammani, A.; James, C.A.; Cadrin-Tourigny, J.; Calkins, H.; van Tintelen, J.P.; Hauer, R.N.W.; Asselbergs, F.W.; Te Riele, A. Predicting arrhythmic risk in arrhythmogenic right ventricular cardiomyopathy: A systematic review and metaanalysis. Heart Rhythm 2018, 15, 1097-1107. [CrossRef]

5. Cadrin-Tourigny, J.; Bosman, L.P.; Nozza, A.; Wang, W.; Tadros, R.; Bhonsale, A.; Bourfiss, M.; Fortier, A.; Lie, O.H.; Saguner, A.M.; et al. A new prediction model for ventricular arrhythmias in arrhythmogenic right ventricular cardiomyopathy. Eur. Heart J. 2019, 40, 1850-1858. [CrossRef] [PubMed] 
6. Calkins, H.; Corrado, D.; Marcus, F. Risk Stratification in Arrhythmogenic Right Ventricular Cardiomyopathy. Circulation 2017, 136, 2068-2082. [CrossRef]

7. Hauer, R.N.W. Prevention of Sudden Cardiac Death in Arrhythmogenic Cardiomyopathy. JACC Clin. Electrophysiol. 2018, 4, 769-770. [CrossRef]

8. Mazzanti, A.; Ng, K.; Faragli, A.; Maragna, R.; Chiodaroli, E.; Orphanou, N.; Monteforte, N.; Memmi, M.; Gambelli, P.; Novelli, V.; et al. Arrhythmogenic Right Ventricular Cardiomyopathy: Clinical Course and Predictors of Arrhythmic Risk. J. Am. Coll. Cardiol. 2016, 68, 2540-2550. [CrossRef] [PubMed]

9. Vischer, A.S.; Castelletti, S.; Syrris, P.; McKenna, W.J.; Pantazis, A. Heart failure in patients with arrhythmogenic right ventricular cardiomyopathy: Genetic characteristics. Int. J. Cardiol. 2019, 286, 99-103. [CrossRef] [PubMed]

10. Gilotra, N.A.; Bhonsale, A.; James, C.A.; Te Riele, A.S.J.; Murray, B.; Tichnell, C.; Sawant, A.; Ong, C.S.; Judge, D.P.; Russell, S.D.; et al. Heart Failure Is Common and Under-Recognized in Patients With Arrhythmogenic Right Ventricular Cardiomyopathy/Dysplasia. Circ. Heart Fail. 2017, 10. [CrossRef] [PubMed]

11. Bhonsale, A.; Groeneweg, J.A.; James, C.A.; Dooijes, D.; Tichnell, C.; Jongbloed, J.D.H.; Murray, B.; Te Riele, A.S.J.M.; Van Den Berg, M.P.; Bikker, H.; et al. Impact of genotype on clinical course in arrhythmogenic right ventricular dysplasia/ cardiomyopathy-associated mutation carriers. Eur. Heart J. 2015, 36, 847-855. [CrossRef]

12. Komura, M.; Suzuki, J.-I.; Adachi, S.; Takahashi, A.; Otomo, K.; Nitta, J.; Nishizaki, M.; Obayashi, T.; Nogami, A.; Satoh, Y.; et al. Clinical Course of Arrhythmogenic Right Ventricular Cardiomyopathy in the Era of Implantable Cardioverter-Defibrillators and Radiofrequency Catheter Ablation. Int. Heart J. 2010, 51, 34-40. [CrossRef]

13. DeWitt, E.S.; Chandler, S.F.; Hylind, R.J.; Beausejour Ladouceur, V.; Blume, E.D.; VanderPluym, C.; Powell, A.J.; Fynn-Thompson, F.; Roberts, A.E.; Sanders, S.P.; et al. Phenotypic Manifestations of Arrhythmogenic Cardiomyopathy in Children and Adolescents. J. Am. Coll. Cardiol. 2019, 74, 346-358. [CrossRef] [PubMed]

14. Groeneweg, J.A.; Bhonsale, A.; James, C.A.; Te Riele, A.S.; Dooijes, D.; Tichnell, C.; Murray, B.; Wiesfeld, A.C.; Sawant, A.C.; Kassamali, B.; et al. Clinical Presentation, Long-Term Follow-Up, and Outcomes of 1001 Arrhythmogenic Right Ventricular Dysplasia/Cardiomyopathy Patients and Family Members. Circ. Cardiovasc. Genet. 2015, 8, 437-446. [CrossRef] [PubMed]

15. Peters, S. Long-term follow-up and risk assessment of arrhythmogenic right ventricular dysplasia/cardiomyopathy: Personal experience from different primary and tertiary centres. J. Cardiovasc. Med. 2007, 8, 521-526. [CrossRef] [PubMed]

16. Peters, S.; Trümmel, M.; Meyners, W. Prevalence of right ventricular dysplasia-cardiomyopathy in a non-referral hospital. Int. J. Cardiol. 2004, 97, 499-501. [CrossRef] [PubMed]

17. Peters, S.; Peters, H.; Thierfelder, L. Heart failure in arrhythmogenic right ventricular dysplasia-cardiomyopathy. Int. J. Cardiol. 1999, 71, 251-256. [CrossRef]

18. Hulot, J.-S.; Jouven, X.; Empana, J.-P.; Frank, R.; Fontaine, G. Natural History and Risk Stratification of Arrhythmogenic Right Ventricular Dysplasia/Cardiomyopathy. Circulation 2004, 110, 1879-1884. [CrossRef]

19. Lemola, K.; Brunckhorst, C.; Helfenstein, U.; Oechslin, E.; Jenni, R.; Duru, F. Predictors of adverse outcome in patients with arrhythmogenic right ventricular dysplasia/cardiomyopathy: Long term experience of a tertiary care centre. Heart 2005, 91, 1167-1172. [CrossRef] [PubMed]

20. Dalal, D.; Nasir, K.; Bomma, C.; Prakasa, K.; Tandri, H.; Piccini, J.; Roguin, A.; Tichnell, C.; James, C.; Russell, S.D.; et al. Arrhythmogenic right ventricular dysplasia: A United States experience. Circulation 2005, 112, 3823-3832. [CrossRef]

21. Watkins, D.A.; Hendricks, N.; Shaboodien, G.; Mbele, M.; Parker, M.; Vezi, B.Z.; Latib, A.; Chin, A.; Little, F.; Badri, M.; et al. Clinical features, survival experience, and profile of plakophylin-2 gene mutations in participants of the Arrhythmogenic Right Ventricular Cardiomyopathy Registry of South Africa. Heart Rhythm 2009, 6, S10-S17. [CrossRef] [PubMed]

22. Pinamonti, B.; Dragos, A.M.; Pyxaras, S.A.; Merlo, M.; Pivetta, A.; Barbati, G.; Di Lenarda, A.; Morgera, T.; Mestroni, L.; Sinagra, G. Prognostic predictors in arrhythmogenic right ventricular cardiomyopathy: Results from a 10-year registry. Eur. Heart J. 2011, 32, 1105-1113. [CrossRef] [PubMed]

23. Saguner, A.M.; Medeiros-Domingo, A.; Schwyzer, M.A.; On, C.-J.; Haegeli, L.M.; Wolber, T.; Hürlimann, D.; Steffel, J.; Krasniqi, N.; Rüeger, S.; et al. Usefulness of Inducible Ventricular Tachycardia to Predict Long-Term Adverse Outcomes in Arrhythmogenic Right Ventricular Cardiomyopathy. Am. J. Cardiol. 2013, 111, 250-257. [CrossRef] [PubMed]

24. Saguner, A.M.; Vecchiati, A.; Baldinger, S.H.; Rüeger, S.; Medeiros-Domingo, A.; Mueller-Burri, A.S.; Haegeli, L.M.; Biaggi, P.; Manka, R.; Lüscher, T.F.; et al. Different prognostic value of functional right ventricular parameters in arrhythmogenic right ventricular cardiomyopathy/dysplasia. Circ. Cardiovasc. Imaging 2014, 7, 230-239. [CrossRef] [PubMed]

25. Saberniak, J.; Hasselberg, N.E.; Borgquist, R.; Platonov, P.G.; Sarvari, S.I.; Smith, H.; Ribe, M.; Holst, A.G.; Edvardsen, T.; Haugaa, K.H. Vigorous physical activity impairs myocardial function in patients with arrhythmogenic right ventricular cardiomyopathy and in mutation positive family members. Eur. J. Heart Fail. 2014, 16, 1337-1344. [CrossRef]

26. Te Riele, A.S.J.M.; James, C.A.; Sawant, A.C.; Bhonsale, A.; Groeneweg, J.A.; Mast, T.P.; Murray, B.; Tichnell, C.; Dooijes, D.; Van Tintelen, J.P.; et al. Arrhythmogenic Right Ventricular Dysplasia/Cardiomyopathy in the Pediatric Population Clinical Characterization and Comparison with Adult-Onset Disease. JACC Clin. Electrophysiol. 2015, 1, 551-560. [CrossRef]

27. Gallo, C.; Blandino, A.; Giustetto, C.; Anselmino, M.; Castagno, D.; Richiardi, E.; Gaita, F. Arrhythmogenic right ventricular cardiomyopathy: ECG progression over time and correlation with long-term follow-up. J. Cardiovasc. Med. 2016, 17, 418-424. [CrossRef] 
28. Kimura, Y.; Noda, T.; Otsuka, Y.; Wada, M.; Nakajima, I.; Ishibashi, K.; Miyamoto, K.; Okamura, H.; Aiba, T.; Kamakura, S.; et al. Potentially Lethal Ventricular Arrhythmias and Heart Failure in Arrhythmogenic Right Ventricular Cardiomyopathy: What Are the Differences Between Men and Women? JACC Clin. Electrophysiol. 2016, 2, 546-555. [CrossRef]

29. Bhonsale, A.; Te Riele, A.S.; Sawant, A.C.; Groeneweg, J.A.; James, C.A.; Murray, B.; Tichnell, C.; Mast, T.P.; van der Pols, M.J.; Cramer, M.J.; et al. Cardiac phenotype and long-term prognosis of arrhythmogenic right ventricular cardiomyopathy/dysplasia patients with late presentation. Heart Rhythm 2017, 14, 883-891. [CrossRef]

30. Gilljam, T.; Haugaa, K.H.; Jensen, H.K.; Svensson, A.; Bundgaard, H.; Hansen, J.; Dellgren, G.; Gustafsson, F.; Eiskjær, H.; Andreassen, A.K.; et al. Heart transplantation in arrhythmogenic right ventricular cardiomyopathy-Experience from the Nordic ARVC Registry. Int. J. Cardiol. 2018, 250, 201-206. [CrossRef]

31. Orgeron, G.M.; James, C.A.; Riele, A.T.; Tichnell, C.; Murray, B.; Bhonsale, A.; Kamel, I.R.; Zimmerman, S.L.; Judge, D.P.; Crosson, J.; et al. Implantable Cardioverter-Defibrillator Therapy in Arrhythmogenic Right Ventricular Dysplasia/Cardiomyopathy: Predictors of Appropriate Therapy, Outcomes, and Complications. J. Am. Heart Assoc. 2017, 6. [CrossRef] [PubMed]

32. Mahida, S.; Venlet, J.; Saguner, A.M.; Kumar, S.; Baldinger, S.H.; AbdelWahab, A.; Tedrow, U.B.; Castelletti, S.; Pantazis, A.; John, R.M.; et al. Ablation compared with drug therapy for recurrent ventricular tachycardia in arrhythmogenic right ventricular cardiomyopathy: Results from a multicenter study. Heart Rhythm 2019, 16, 536-543. [CrossRef] [PubMed]

33. Liang, E.; Wu, L.; Fan, S.; Li, X.; Hu, F.; Zheng, L.; Fan, X.; Chen, G.; Ding, L.; Yao, Y. Bradyarrhythmias in Arrhythmogenic Right Ventricular Cardiomyopathy. Am. J. Cardiol. 2019, 123, 1690-1695. [CrossRef]

34. Mathew, S.; Saguner, A.M.; Schenker, N.; Kaiser, L.; Zhang, P.; Yashuiro, Y.; Lemes, C.; Fink, T.; Maurer, T.; Santoro, F.; et al. Catheter Ablation of Ventricular Tachycardia in Patients With Arrhythmogenic Right Ventricular Cardiomyopathy/Dysplasia: A Sequential Approach. J. Am. Heart Assoc. 2019, 8, e010365. [CrossRef] [PubMed]

35. Laredo, M.; Da Silva, L.O.; Extramiana, F.; Lellouche, N.; Varlet, É.; Amet, D.; Algalarrondo, V.; Waintraub, X.; Duthoit, G.; Badenco, N.; et al. Catheter ablation of electrical storm in patients with arrhythmogenic right ventricular cardiomyopathy. Heart Rhythm 2020, 17, 41-48. [CrossRef]

36. Hermida, A.; Fressart, V.; Hidden-Lucet, F.; Donal, E.; Probst, V.; Deharo, J.C.; Chevalier, P.; Klug, D.; Mansencal, N.; Delacretaz, E.; et al. High risk of heart failure associated with desmoglein-2 mutations compared to plakophilin-2 mutations in arrhythmogenic right ventricular cardiomyopathy/dysplasia. Eur. J. Heart Fail. 2019, 21, 792-800. [CrossRef]

37. Bosman, L.P.; Verstraelen, T.E.; van Lint, F.H.M.; Cox, M.; Groeneweg, J.A.; Mast, T.P.; van der Zwaag, P.A.; Volders, P.G.A.; Evertz, R.; Wong, L.; et al. The Netherlands Arrhythmogenic Cardiomyopathy Registry: Design and status update. Neth. Heart J. 2019, 27, 480-486. [CrossRef]

38. Kimura, Y.; Noda, T.; Matsuyama, T.-A.; Otsuka, Y.; Kamakura, T.; Wada, M.; Ishibashi, K.; Inoue, Y.; Miyamoto, K.; Okamura, H.; et al. Heart failure in patients with arrhythmogenic right ventricular cardiomyopathy: What are the risk factors? Int. J. Cardiol. 2017, 241, 288-294. [CrossRef]

39. Camm, C.F.; James, C.A.; Tichnell, C.; Murray, B.; Bhonsale, A.; Te Riele, A.; Judge, D.P.; Tandri, H.; Calkins, H. Prevalence of atrial arrhythmias in arrhythmogenic right ventricular dysplasia/cardiomyopathy. Heart Rhythm 2013, 10, 1661-1668. [CrossRef]

40. Girard, F.; Fontaine, G.; Fontaliran, F.; Zenati, O.; Gajdos, P. Catastrophic global heart failure in a patient with non-arrhythmogenic right ventricular dysplasia. Heart Vessel. 1997, 12, 152-154. [CrossRef]

41. Corrado, D.; Fontaine, G.; Marcus, F.I.; McKenna, W.J.; Nava, A.; Thiene, G.; Wichter, T. Arrhythmogenic right ventricular dysplasia/cardiomyopathy: Need for an international registry. Study Group on Arrhythmogenic Right Ventricular Dysplasia/Cardiomyopathy of the Working Groups on Myocardial and Pericardial Disease and Arrhythmias of the European Society of Cardiology and of the Scientific Council on Cardiomyopathies of the World Heart Federation. Circulation 2000, 101, E101-E106.

42. Chen, L.; Song, J.; Chen, X.; Chen, K.; Ren, J.; Zhang, N.; Rao, M.; Hu, Z.; Zhang, Y.; Gu, M.; et al. A novel genotype-based clinicopathology classification of arrhythmogenic cardiomyopathy provides novel insights into disease progression. Eur. Heart $J$. 2019, 40, 1690-1703. [CrossRef]

43. Marcus, F.I.; McKenna, W.J.; Sherrill, D.; Basso, C.; Bauce, B.; Bluemke, D.A.; Calkins, H.; Corrado, D.; Cox, M.G.; Daubert, J.P.; et al. Diagnosis of arrhythmogenic right ventricular cardiomyopathy/dysplasia: Proposed Modification of the Task Force Criteria. Eur. Heart J. 2010, 31, 806-814. [CrossRef] [PubMed]

44. Yancy, C.W.; Jessup, M.; Bozkurt, B.; Butler, J.; Casey, D.E., Jr.; Drazner, M.H.; Fonarow, G.C.; Geraci, S.A.; Horwich, T.; Januzzi, J.L.; et al. 2013 ACCF/AHA guideline for the management of heart failure: A report of the American College of Cardiology Foundation/American Heart Association Task Force on Practice Guidelines. J. Am. Coll. Cardiol. 2013, 62, e147-e239. [CrossRef] [PubMed]

45. Bernard, Y.; Meneveau, N.; Boucher, S.; Magnin, D.; Anguenot, T.; Schiele, F.; Vuillemenot, A.; Bassand, J.-P. Lack of agreement between left ventricular volumes and ejection fraction determined by two-dimensional echocardiography and contrast cineangiography in postinfarction patients. Echocardiography 2001, 18, 113-122. [CrossRef] [PubMed]

46. Chen, X.; Li, L.; Cheng, H.; Song, Y.; Ji, K.; Chen, L.; Han, T.; Lu, M.; Zhao, S. Early Left Ventricular Involvement Detected by Cardiovascular Magnetic Resonance Feature Tracking in Arrhythmogenic Right Ventricular Cardiomyopathy: The Effects of Left Ventricular Late Gadolinium Enhancement and Right Ventricular Dysfunction. J. Am. Heart Assoc. 2019, 8, e012989. [CrossRef] [PubMed] 
47. Cipriani, A.; Bauce, B.; De Lazzari, M.; Rigato, I.; Bariani, R.; Meneghin, S.; Pilichou, K.; Motta, R.; Aliberti, C.; Thiene, G.; et al. Arrhythmogenic Right Ventricular Cardiomyopathy: Characterization of Left Ventricular Phenotype and Differential Diagnosis With Dilated Cardiomyopathy. J. Am. Heart Assoc. 2020, 9, e014628. [CrossRef]

48. Saguner, A.M.; Ganahl, S.; Kraus, A.; Baldinger, S.H.; Akdis, D.; Saguner, A.R.; Wolber, T.; Haegeli, L.M.; Steffel, J.; Krasniqi, N.; et al. Electrocardiographic features of disease progression in arrhythmogenic right ventricular cardiomyopathy/dysplasia. $B M C$ Cardiovasc. Disord. 2015, 15, 4. [CrossRef]

49. Roberts, W.C.; Kondapalli, N.; Hall, S.A. Usefulness of Total 12-Lead QRS Voltage for Diagnosis of Arrhythmogenic Right Ventricular Cardiomyopathy in Patients With Heart Failure Severe Enough to Warrant Orthotopic Heart Transplantation and Morphologic Illustration of Its Cardiac Diversity. Am. J. Cardiol. 2018, 122, 1051-1061. [CrossRef]

50. Saguner, A.M.; Ganahl, S.; Baldinger, S.H.; Kraus, A.; Medeiros-Domingo, A.; Nordbeck, S.; Saguner, A.R.; Mueller-Burri, A.S.; Haegeli, L.M.; Wolber, T.; et al. Usefulness of Electrocardiographic Parameters for Risk Prediction in Arrhythmogenic Right Ventricular Dysplasia. Am. J. Cardiol. 2014, 113, 1728-1734. [CrossRef]

51. Cheng, H.; Lu, M.; Hou, C.; Chen, X.; Wang, J.; Yin, G.; Chu, J.; Zhang, S.; Prasad, S.K.; Pu, J.; et al. Relation Between N-Terminal Pro-Brain Natriuretic Peptide and Cardiac Remodeling and Function Assessed by Cardiovascular Magnetic Resonance Imaging in Patients With Arrhythmogenic Right Ventricular Cardiomyopathy. Am. J. Cardiol. 2015, 115, 341-347. [CrossRef]

52. Matsuo, K.; Nishikimi, T.; Yutani, C.; Kurita, T.; Shimizu, W.; Taguchi, A.; Suyama, K.; Aihara, N.; Kamakura, S.; Kangawa, K.; et al. Diagnostic Value of Plasma Levels of Brain Natriuretic Peptide in Arrhythmogenic Right Ventricular Dysplasia. Circulation 1998, 98, 2433-2440. [CrossRef] [PubMed]

53. Wei, Y.-J.; Huang, Y.-X.; Shen, Y.; Cui, C.-J.; Zhang, X.-L.; Zhang, H.; Hu, S.-S. Proteomic analysis reveals significant elevation of heat shock protein 70 in patients with chronic heart failure due to arrhythmogenic right ventricular cardiomyopathy. Mol. Cell. Biochem. 2009, 332, 103-111. [CrossRef] [PubMed]

54. Asimaki, A. BIN1: A new biomarker to track ARVC? Heart Rhythm 2012, 9, 968-969. [CrossRef] [PubMed]

55. Hong, T.-T.; Cogswell, R.; James, C.A.; Kang, G.; Pullinger, C.R.; Malloy, M.J.; Kane, J.P.; Wojciak, J.; Calkins, H.; Scheinman, M.M.; et al. Plasma BIN1 correlates with heart failure and predicts arrhythmia in patients with arrhythmogenic right ventricular cardiomyopathy. Heart Rhythm 2012, 9, 961-967. [CrossRef] [PubMed]

56. Broch, K.; Leren, I.S.; Saberniak, J.; Ueland, T.; Edvardsen, T.; Gullestad, L.; Haugaa, K.H. Soluble ST2 is associated with disease severity in arrhythmogenic right ventricular cardiomyopathy. Biomarkers 2017, 22, 367-371. [CrossRef]

57. Oz, F.; Onur, I.; Elitok, A.; Ademoglu, E.; Altun, I.; Bilge, A.K.; Adalet, K. Galectin-3 correlates with arrhythmogenic right ventricular cardiomyopathy and predicts the risk of ventricular arrhythmias in patients with implantable defibrillators. Acta Cardiol. 2017, 72, 453-459. [CrossRef] [PubMed]

58. Ren, J.; Tsilafakis, K.; Chen, L.; Lekkos, K.; Kostavasili, I.; Varela, A.; Cokkinos, D.V.; Davos, C.H.; Sun, X.; Song, J.; et al. Crosstalk between coagulation and complement activation promotes cardiac dysfunction in arrhythmogenic right ventricular cardiomyopathy. Theranostics 2021, 11, 5939-5954. [CrossRef]

59. van der Voorn, S.M.; Te Riele, A.; Basso, C.; Calkins, H.; Remme, C.A.; van Veen, T.A.B. Arrhythmogenic cardiomyopathy: Pathogenesis, pro-arrhythmic remodelling, and novel approaches for risk stratification and therapy. Cardiovasc. Res. 2020, 116, 1571-1584. [CrossRef]

60. Casella, M.; Bergonti, M.; Dello Russo, A.; Maragna, R.; Gasperetti, A.; Compagnucci, P.; Catto, V.; Trombara, F.; Frappampina, A.; Conte, E.; et al. Endomyocardial Biopsy: The Forgotten Piece in the Arrhythmogenic Cardiomyopathy Puzzle. J. Am. Heart Assoc. 2021, 10, e021370. [CrossRef]

61. Lutokhina, Y.; Blagova, O.; Nedostup, A.; Alexandrova, S.; Shestak, A.; Zaklyazminskaya, E. Clinical Classification of Arrhythmogenic Right Ventricular Cardiomyopathy. Pulse 2020, 8, 21-30. [CrossRef] [PubMed]

62. Duru, F.; Hauer, R.N.W. Multiple facets of arrhythmogenic cardiomyopathy: The Fuwai classification of a unique disease based on clinical features, histopathology, and genotype. Eur. Heart J. 2019, 40, 1704-1706. [CrossRef]

63. Bauce, B.; Frigo, G.; Marcus, F.I.; Basso, C.; Rampazzo, A.; Maddalena, F.; Corrado, D.; Winnicki, M.; Daliento, L.; Rigato, I.; et al. Comparison of Clinical Features of Arrhythmogenic Right Ventricular Cardiomyopathy in Men Versus Women. Am. J. Cardiol. 2008, 102, 1252-1257. [CrossRef] [PubMed]

64. Fitzpatrick, J.R., 3rd; Frederick, J.R.; Hsu, V.M.; Kozin, E.D.; O’Hara, M.L.; Howell, E.; Dougherty, D.; McCormick, R.C.; Laporte, C.A.; Cohen, J.E.; et al. Risk score derived from pre-operative data analysis predicts the need for biventricular mechanical circulatory support. J. Heart Lung Transplant. 2008, 27, 1286-1292. [CrossRef] [PubMed]

65. Ochiai, Y.; McCarthy, P.M.; Smedira, N.G.; Banbury, M.K.; Navia, J.L.; Feng, J.; Hsu, A.P.; Yeager, M.L.; Buda, T.; Hoercher, K.J.; et al. Predictors of severe right ventricular failure after implantable left ventricular assist device insertion: Analysis of 245 patients. Circulation 2002, 106, I-198-I-202.

66. Caforio, A.L.P.; Re, F.; Avella, A.; Marcolongo, R.; Baratta, P.; Seguso, M.; Gallo, N.; Plebani, M.; Izquierdo-Bajo, A.; Cheng, C.Y.; et al. Evidence From Family Studies for Autoimmunity in Arrhythmogenic Right Ventricular Cardiomyopathy: Associations of Circulating Anti-Heart and Anti-Intercalated Disk Autoantibodies With Disease Severity and Family History. Circulation 2020, 141, 1238-1248. [CrossRef] [PubMed] 
67. Groeneweg, J.A.; van der Zwaag, P.A.; Olde Nordkamp, L.R.; Bikker, H.; Jongbloed, J.D.; Jongbloed, R.; Wiesfeld, A.C.; Cox, M.G.; van der Heijden, J.F.; Atsma, D.E.; et al. Arrhythmogenic Right Ventricular Dysplasia/Cardiomyopathy According to Revised 2010 Task Force Criteria With Inclusion of Non-Desmosomal Phospholamban Mutation Carriers. Am. J. Cardiol. 2013, 112, 1197-1206. [CrossRef]

68. Link, M.S.; Laidlaw, D.; Polonsky, B.; Zareba, W.; McNitt, S.; Gear, K.; Marcus, F.; Estes, N.A., 3rd. Ventricular arrhythmias in the North American multidisciplinary study of ARVC: Predictors, characteristics, and treatment. J. Am. Coll. Cardiol. 2014, 64, 119-125. [CrossRef]

69. Peters, S.; Trümmel, M.; Koehler, B. Special features of right bundle branch block in patients with arrhythmogenic right ventricular cardiomyopathy/dysplasia. Int. J. Cardiol. 2012, 157, 102-103. [CrossRef]

70. Fressart, V.; Duthoit, G.; Donal, E.; Probst, V.; Deharo, J.-C.; Chevalier, P.; Klug, D.; Dubourg, O.; Delacretaz, E.; Cosnay, P.; et al Desmosomal gene analysis in arrhythmogenic right ventricular dysplasia/cardiomyopathy: Spectrum of mutations and clinical impact in practice. Europace 2010, 12, 861-868. [CrossRef]

71. Chen, L.; Rao, M.; Chen, X.; Chen, K.; Ren, J.; Zhang, N.; Zhao, Q.; Yu, W.; Yuan, B.; Song, J. A founder homozygous DSG2 variant in East Asia results in ARVC with full penetrance and heart failure phenotype. Int. J. Cardiol. 2019, 274, 263-270. [CrossRef]

72. Castelletti, S.; Vischer, A.S.; Syrris, P.; Crotti, L.; Spazzolini, C.; Ghidoni, A.; Parati, G.; Jenkins, S.; Kotta, M.-C.; McKenna, W.J.; et al. Desmoplakin missense and non-missense mutations in arrhythmogenic right ventricular cardiomyopathy: Genotype-phenotype correlation. Int. J. Cardiol. 2017, 249, 268-273. [CrossRef] [PubMed]

73. Bauce, B.; Rampazzo, A.; Basso, C.; Mazzotti, E.; Rigato, I.; Steriotis, A.; Beffagna, G.; Lorenzon, A.; De Bortoli, M.; Pilichou, K.; et al. Clinical phenotype and diagnosis of arrhythmogenic right ventricular cardiomyopathy in pediatric patients carrying desmosomal gene mutations. Heart Rhythm 2011, 8, 1686-1695. [CrossRef] [PubMed]

74. Sen-Chowdhry, S.; Syrris, P.; Ward, D.; Asimaki, A.; Sevdalis, E.; McKenna, W.J. Clinical and Genetic Characterization of Families With Arrhythmogenic Right Ventricular Dysplasia/Cardiomyopathy Provides Novel Insights Into Patterns of Disease Expression. Circulation 2007, 115, 1710-1720. [CrossRef]

75. Norman, M.; Simpson, M.; Mogensen, J.; Shaw, A.; Hughes, S.; Syrris, P.; Sen-Chowdhry, S.; Rowland, E.; Crosby, A.; McKenna, W.J. Novel Mutation in Desmoplakin Causes Arrhythmogenic Left Ventricular Cardiomyopathy. Circulation 2005, 112, 636-642. [CrossRef] [PubMed]

76. Norgett, E.E.; Hatsell, S.J.; Carvajal-Huerta, L.; Cabezas, J.C.; Common, J.; Purkis, P.E.; Whittock, N.; Leigh, I.M.; Stevens, H.P.; Kelsell, D.P. Recessive mutation in desmoplakin disrupts desmoplakin-intermediate filament interactions and causes dilated cardiomyopathy, woolly hair and keratoderma. Hum. Mol. Genet. 2000, 9, 2761-2766. [CrossRef]

77. Fish, M.; Shaboodien, G.; Kraus, S.; Sliwa, K.; Seidman, C.E.; Burke, M.A.; Crotti, L.; Schwartz, P.J.; Mayosi, B.M. Mutation analysis of the phospholamban gene in 315 South Africans with dilated, hypertrophic, peripartum and arrhythmogenic right ventricular cardiomyopathies. Sci. Rep. 2016, 6, 22235. [CrossRef]

78. Groeneweg, J.A.; van der Zwaag, P.A.; Jongbloed, J.D.; Cox, M.G.; Vreeker, A.; de Boer, R.A.; van der Heijden, J.F.; van Veen, T.A.; McKenna, W.J.; van Tintelen, J.P.; et al. Left-dominant arrhythmogenic cardiomyopathy in a large family: Associated desmosomal or nondesmosomal genotype? Heart Rhythm 2013, 10, 548-559. [CrossRef]

79. van der Zwaag, P.A.; van Rijsingen, I.A.; Asimaki, A.; Jongbloed, J.D.; van Veldhuisen, D.J.; Wiesfeld, A.C.; Cox, M.G.; van Lochem, L.T.; de Boer, R.A.; Hofstra, R.M.; et al. Phospholamban R14del mutation in patients diagnosed with dilated cardiomyopathy or arrhythmogenic right ventricular cardiomyopathy: Evidence supporting the concept of arrhythmogenic cardiomyopathy. Eur. J. Heart Fail. 2012, 14, 1199-1207. [CrossRef]

80. van der Zwaag, P.A.; van Rijsingen, I.A.; de Ruiter, R.; Nannenberg, E.A.; Groeneweg, J.A.; Post, J.G.; Hauer, R.N.; van Gelder, I.C.; van den Berg, M.P.; van der Harst, P.; et al. Recurrent and founder mutations in the Netherlands-Phospholamban p.Arg14del mutation causes arrhythmogenic cardiomyopathy. Neth. Heart J. 2013, 21, 286-293. [CrossRef]

81. van Rijsingen, I.A.; van der Zwaag, P.A.; Groeneweg, J.A.; Nannenberg, E.A.; Jongbloed, J.D.; Zwinderman, A.H.; Pinto, Y.M.; Dit Deprez, R.H.; Post, J.G.; Tan, H.L.; et al. Outcome in phospholamban R14del carriers: Results of a large multicentre cohort study. Circ. Cardiovasc. Genet. 2014, 7, 455-465. [CrossRef]

82. Brun, F.; Barnes, C.V.; Sinagra, G.; Slavov, D.; Barbati, G.; Zhu, X.; Graw, S.L.; Spezzacatene, A.; Pinamonti, B.; Merlo, M.; et al. Titin and desmosomal genes in the natural history of arrhythmogenic right ventricular cardiomyopathy. J. Med. Genet. 2014, 51, 669-676. [CrossRef] [PubMed]

83. Chen, Z.; Song, J.; Chen, L.; Zhu, C.; Cai, H.; Sun, M.; Stern, A.; Mozdziak, P.; Ge, Y.; Means, W.J.; et al. Characterization of TTN Novex Splicing Variants across Species and the Role of RBM20 in Novex-Specific Exon Splicing. Genes 2018, 9, 86. [CrossRef] [PubMed]

84. Chen, K.; Song, J.; Wang, Z.; Rao, M.; Chen, L.; Hu, S. Absence of a primary role for TTN missense variants in arrhythmogenic cardiomyopathy: From a clinical and pathological perspective. Clin. Cardiol. 2018, 41, 615-622. [CrossRef] [PubMed]

85. Rao, M.; Guo, G.; Li, M.; Chen, S.; Chen, K.; Chen, X.; Song, J.; Hu, S. The homozygous variant c.245G > A/p.G82D in PNPLA2 is associated with arrhythmogenic cardiomyopathy phenotypic manifestations. Clin. Genet. 2019, 96, 532-540. [CrossRef] [PubMed]

86. Krusche, C.A.; Holthöfer, B.; Hofe, V.; van de Sandt, A.M.; Eshkind, L.; Bockamp, E.; Merx, M.W.; Kant, S.; Windoffer, R.; Leube, R.E. Desmoglein 2 mutant mice develop cardiac fibrosis and dilation. Basic Res. Cardiol. 2011, 106, 617-633. [CrossRef] [PubMed] 
87. Miles, C.; Finocchiaro, G.; Papadakis, M.; Gray, B.; Westaby, J.; Ensam, B.; Basu, J.; Parry-Williams, G.; Papatheodorou, E.; Paterson, C.; et al. Sudden Death and Left Ventricular Involvement in Arrhythmogenic Cardiomyopathy. Circulation 2019, 139, 1786-1797. [CrossRef] [PubMed]

88. Cheung, C.C.; Laksman, Z.W.; Mellor, G.; Sanatani, S.; Krahn, A.D. Exercise and Inherited Arrhythmias. Can. J. Cardiol. 2016, 32, 452-458. [CrossRef] [PubMed]

89. Cadrin-Tourigny, J.; Bosman, L.P.; Tadros, R.; Talajic, M.; Rivard, L.; James, C.A.; Khairy, P. Risk stratification for ventricular arrhythmias and sudden cardiac death in arrhythmogenic right ventricular cardiomyopathy: An update. Expert Rev. Cardiovasc. Ther. 2019, 17, 645-651. [CrossRef]

90. Costa, S.; Gasperetti, A.; Medeiros-Domingo, A.; Akdis, D.; Brunckhorst, C.; Saguner, A.M.; Duru, F. Familial Arrhythmogenic Cardiomyopathy: Clinical Determinants of Phenotype Discordance and the Impact of Endurance Sports. J. Clin. Med. 2020, 9 , 3781. [CrossRef]

91. Akdis, D.; Saguner, A.M.; Burri, H.; Medeiros-Domingo, A.; Matter, C.M.; Ruschitzka, F.; Tanner, F.C.; Brunckhorst, C.; Duru, F. Clinical predictors of left ventricular involvement in arrhythmogenic right ventricular cardiomyopathy. Am. Heart J. 2020, 223, 34-43. [CrossRef]

92. Corrado, D.; Basso, C.; Thiene, G.; McKenna, W.J.; Davies, M.J.; Fontaliran, F.; Nava, A.; Silvestri, F.; Blomstrom-Lundqvist, C.; Wlodarska, E.K.; et al. Spectrum of Clinicopathologic Manifestations of Arrhythmogenic Right Ventricular Cardiomyopathy /Dysplasia: A Multicenter Study. J. Am. Coll. Cardiol. 1997, 30, 1512-1520. [CrossRef]

93. Maron, B.J.; Chaitman, B.R.; Ackerman, M.J.; Bayes de Luna, A.; Corrado, D.; Crosson, J.E.; Deal, B.J.; Driscoll, D.J.; Estes, N.A., 3rd; Araujo, C.G.; et al. Recommendations for physical activity and recreational sports participation for young patients with genetic cardiovascular diseases. Circulation 2004, 109, 2807-2816. [CrossRef]

94. Ruwald, A.C.; Marcus, F.; Estes, N.A., 3rd; Link, M.; McNitt, S.; Polonsky, B.; Calkins, H.; Towbin, J.A.; Moss, A.J.; Zareba, W. Association of competitive and recreational sport participation with cardiac events in patients with arrhythmogenic right ventricular cardiomyopathy: Results from the North American multidisciplinary study of arrhythmogenic right ventricular cardiomyopathy. Eur. Heart J. 2015, 36, 1735-1743. [CrossRef] [PubMed]

95. Towbin, J.A.; McKenna, W.J.; Abrams, D.J.; Ackerman, M.J.; Calkins, H.; Darrieux, F.C.C.; Daubert, J.P.; de Chillou, C.; DePasquale, E.C.; Desai, M.Y.; et al. 2019 HRS expert consensus statement on evaluation, risk stratification, and management of arrhythmogenic cardiomyopathy. Heart Rhythm 2019, 16, e301-e372. [CrossRef]

96. McDonagh, T.A.; Metra, M.; Adamo, M.; Gardner, R.S.; Baumbach, A.; Böhm, M.; Burri, H.; Butler, J.; Čelutkienė, J.; Chioncel, O.; et al. 2021 ESC Guidelines for the diagnosis and treatment of acute and chronic heart failure. Eur. Heart J. 2021, 42, 3599-3726. [CrossRef]

97. Haugaa, K.H.; Bundgaard, H.; Edvardsen, T.; Eschen, O.; Gilljam, T.; Hansen, J.; Jensen, H.K.; Platonov, P.G.; Svensson, A.; Svendsen, J.H. Management of patients with Arrhythmogenic Right Ventricular Cardiomyopathy in the Nordic countries. Scand. Cardiovasc. J. 2015, 49, 299-307. [CrossRef]

98. Nagendran, J.; Archer, S.L.; Soliman, D.; Gurtu, V.; Moudgil, R.; Haromy, A.; St Aubin, C.; Webster, L.; Rebeyka, I.M.; Ross, D.B.; et al. Phosphodiesterase type 5 is highly expressed in the hypertrophied human right ventricle, and acute inhibition of phosphodiesterase type 5 improves contractility. Circulation 2007, 116, 238-248. [CrossRef] [PubMed]

99. Valente, M.; Calabrese, F.; Thiene, G.; Angelini, A.; Basso, C.; Nava, A.; Rossi, L. In vivo evidence of apoptosis in arrhythmogenic right ventricular cardiomyopathy. Am. J. Pathol. 1998, 152, 479-484. [PubMed]

100. Corrado, D.; Wichter, T.; Link, M.S.; Hauer, R.; Marchlinski, F.; Anastasakis, A.; Bauce, B.; Basso, C.; Brunckhorst, C.; Tsatsopoulou, A.; et al. Treatment of arrhythmogenic right ventricular cardiomyopathy/dysplasia: An international task force consensus statement. Eur. Heart J. 2015, 36, 3227-3237. [CrossRef] [PubMed]

101. Akdis, D.; Chen, K.; Saguner, A.M.; Stämpfli, S.F.; Chen, X.; Chen, L.; Rao, M.; Haegeli, L.M.; Tanner, F.C.; Brunckhorst, C.; et al. Clinical Characteristics of Patients with a Right Ventricular Thrombus in Arrhythmogenic Right Ventricular Cardiomyopathy. Thromb. Haemost. 2019, 119, 1373-1378. [CrossRef]

102. Chachques, J.C.; Argyriadis, P.G.; Fontaine, G.; Hebert, J.-L.; Frank, R.A.; D’Attellis, N.; Fabiani, J.-N.; Carpentier, A.F. Right ventricular cardiomyoplasty: 10-year follow-up. Ann. Thorac. Surg. 2003, 75, 1464-1468. [CrossRef]

103. Zacharias, J.; Forty, J.; Doig, J.C.; Bourke, J.P.; Hilton, C.J. Right ventricular disarticulation. An 18-year single centre experience. Eur. J. Cardiothorac. Surg. 2005, 27, 1000-1004. [CrossRef]

104. Bakir, I.; Brugada, P.; Sarkozy, A.; Vandepitte, C.; Wellens, F. A novel treatment strategy for therapy refractory ventricular arrhythmias in the setting of arrhythmogenic right ventricular dysplasia. Europace 2007, 9, 267-269. [CrossRef]

105. Coleman, M.A.; Bos, J.M.; Johnson, J.N.; Owen, H.J.; Deschamps, C.; Moir, C.; Ackerman, M.J. Videoscopic Left Cardiac Sympathetic Denervation for Patients With Recurrent Ventricular Fibrillation/Malignant Ventricular Arrhythmia Syndromes Besides Congenital Long-QT Syndrome. Circ. Arrhythmia Electrophysiol. 2012, 5, 782-788. [CrossRef]

106. McGiffin, D.; Kure, C.; McLean, J.; Marasco, S.; Bergin, P.; Hare, J.L.; Leet, A.; Patel, H.; Zimmet, A.; Rix, J.; et al. The results of a single-center experience with HeartMate 3 in a biventricular configuration. J. Heart Lung Transplant. 2021, 40, 193-200. [CrossRef]

107. Minegishi, S.; Kinoshita, O.; Hoshino, Y.; Komae, H.; Kimura, M.; Shimada, S.; Yamauchi, H.; Nawata, K.; Ono, M. Long-term support by left ventricular assist device for arrhythmogenic right ventricular cardiomyopathy. Artif. Organs 2019, 43, 909-912. [CrossRef] 
108. Mufti, H.N.; Rajda, M.; Légaré, J.-F. Arrhythmogenic right ventricular cardiomyopathy: Use of a left ventricular assist device as a bridge to transplantation? J. Artif. Organs 2013, 16, 498-500. [CrossRef] [PubMed]

109. Yoshioka, D.; Toda, K.; Yoshikawa, Y.; Sawa, Y. Over 1200-day support with dual Jarvik 2000 biventricular assist device. Interact. Cardiovasc. Thorac. Surg. 2014, 19, 1083-1084. [CrossRef] [PubMed]

110. Bellavia, D.; Iacovoni, A.; Scardulla, C.; Moja, L.; Pilato, M.; Kushwaha, S.S.; Senni, M.; Clemenza, F.; Agnese, V.; Falletta, C.; et al. Prediction of right ventricular failure after ventricular assist device implant: Systematic review and meta-analysis of observational studies. Eur. J. Heart Fail. 2017, 19, 926-946. [CrossRef] [PubMed]

111. Hsiao, C.C.; Kuo, J.Y.; Yun, C.H.; Hung, C.L.; Tsai, C.H.; Yeh, H.I. Rare case of left-dominant arrhythmogenic right ventricular cardiomyopathy with dramatic reverse remodeling after cardiac resynchronization as an adjunct to pharmacological therapy. Heart Lung 2012, 41, e39-e43. [CrossRef] [PubMed]

112. Mehra, M.R.; Canter, C.E.; Hannan, M.M.; Semigran, M.J.; Uber, P.A.; Baran, D.A.; Danziger-Isakov, L.; Kirklin, J.K.; Kirk, R.; Kushwaha, S.S.; et al. The 2016 International Society for Heart Lung Transplantation listing criteria for heart transplantation: A 10-year update. J. Heart Lung Transplant. 2016, 35, 1-23. [CrossRef] [PubMed]

113. DePasquale, E.C.; Cheng, R.K.; Deng, M.C.; Nsair, A.; McKenna, W.J.; Fonarow, G.C.; Jacoby, D.L. Survival After Heart Transplantation in Patients With Arrhythmogenic Right Ventricular Cardiomyopathy. J. Card. Fail. 2017, 23, 107-112. [CrossRef]

114. Tedford, R.J.; James, C.; Judge, D.P.; Tichnell, C.; Murray, B.; Bhonsale, A.; Philips, B.; Abraham, T.; Dalal, D.; Halushka, M.K.; et al. Cardiac Transplantation in Arrhythmogenic Right Ventricular Dysplasia/Cardiomyopathy. J. Am. Coll. Cardiol. 2012, 59, 289-290. [CrossRef] 